\title{
THE PATH OF AMERICAN JURISPRUDENCE
}

\section{G. EDWARD WhITE $\dagger$}

This Article seeks to identify some indigenous characteristics of American jurisprudence, to offer an explanation for their presence, and to explore some of their ramifications over time. The principal thesis of the Article is that the social and intellectual climate in which the English common law functioned in America was markedly unlike that in England, and that this climate, which included the experiences of the American Revolution, stimulated attitudes toward law and legal institutions that were unique rather than derivative. These attitudes have remained part of the educational experience of American lawyers since the eighteenth century, notwithstanding the dramatic changes in American society in the last two hundred years.

Three unique features of American jurisprudence emerge: the belief that "common" or "nonconstitutional" law, ${ }^{1}$ however defined, must continually reflect currently held social attitudes; the tradition of a written constitution as the ultimate source of legal principles; and the delegation of lawmaking power to a "constitutionalizing" agent of government. The function of that agent (primarily but not exclusively the judiciary and most often the Supreme Court, representing the federal judiciary) is to integrate constitutional principles with changing social attitudes and values as manifested in nonconstitutional "laws." Part One of the Article discusses the origins of each of these features; Part Two assesses some of their implications for the development of

$\dagger$ Associate Professor of Law, University of Virginia. B.A. 1963, Amherst College; M.A. 1964, Ph.D. 1967, Yale University; J.D. 1970, Harvard University. Member, Virginia and District of Columbia Bars.

"The term "common law" as used herein refers, first, to nonstatutory English law received in the American colonies prior to the Revolution; second, to nonstatutory law propagated by American judges and juries prior to the passage of the Constitution; third, to nonstatutory, nonconstitutional law propagated by judges from the passage of the Constitution to the end of the second decade of the nineteenth century. The term "common law" is used only metaphorically in referring to developments after 1820 that reveal an entrenched role for the judiciary. The term "nonconstitutional law" includes statutory, administrative, and judicial lawmaking outside the ambit of the Constitution. 
constitutional law and legal scholarship in America. Although much of the material discussed here may be familiar, the Article seeks to offer some fresh perspectives.

\section{The Origins of American Jurisprudence}

\section{A. Common Law and Social Attitudes in Prerevolutionary America}

The patterns of English settlement in colonial America were diverse. Some colonies began as self-conscious missions, others episodes in adventure and enterprise. ${ }^{2}$ In every colony, however, differences from England became apparent immediately. Severity of climate and terrain, an abundance of open land, sparsity of population, remoteness from centers of commerce, learning, and culture, and the absence of established settlements with formal status distinctions and social habits meant that England could not be duplicated in America. Although colonial towns often attempted to transplant English customs and practices, ${ }^{3}$ modifications were inevitable. From this experience came a tacit assumption of colonial life: English institutions were to be perpetuated in America only if they could be made to harmonize with the new environment.

Examples were the offices of lawyer and judge. By the seventeenth century the English bench and bar had become professionalized, with structured patterns of education and achievement. ${ }^{4}$ America did not have enough lawyers, clients, or source materials to replicate such an approach. By the revolutionary generation professionalization of the colonial bars had only begun. (High-level judgeships remained available to nonlawyers throughout the eighteenth century.) ${ }^{5}$ As county courts,

2 Compare the Puritans' seventeenth century settlement of Massachusetts with the Duke of York's "conquest" of New York in the same century.

${ }^{3}$ One example is described in S. Powell, Puritan Village (1963).

${ }^{4}$ See D. Boorstin, The Americans: The Colonial Experience 195-97 (1958); Plucknett, The Place of the Legal Profession in the History of English Law, 48 L.Q. REv. 328, 332-36, 338-39 (1932). The professionalization of the English bar was reflected in the specialization of English lawyers. "Barristers" comprised the top echelon of the English bar and pleaded in the High Courts. "Attorneys" initiated court action for a client but were not permitted to plead in the High Courts. "Solicitors" could neither plead in the High Courts nor initiate lawsuits, but dealt with a client's routine legal problems. $D$. BOoRstin, supra, at 195-96.

${ }^{5}$ See D. Boorstin, supra note 4, at 195-202. Many states still have nonlawyer judges in courts not of record. The Supreme Court is currently considering the constitutionality of Kentucky's practice of having nonlawyer judges preside over criminal trials. North v. Russell, 516 S.W.2d 103 (Ky.), vacated, 419 U.S. 1085 (1974), prob. juris, noted, 422 U.S. 1040 (1975). 
which combined legislative, executive, and judicial functions, became centers of trade and social intercourse in the colonies, the office of justice of the peace came to resemble that of an ombudsman, having varied informal powers of a quasilegal nature. Untrained judges like John Dudley of New Hampshire, who "never was able to write five consecutive sentences in correct English,"6 came to equate "law" with roughspun equities. Dudley is reported to have instructed a jury "to do justice between the parties, not by any quirks of the law out of Coke or Blackstone-books that I never read and never will-but by common sense as between man and man." Thomas Hutchinson, who served as Chief Justice of the Massachusetts Superior Court despite his lack of legal training, confessed that " $[\mathrm{t}]$ he most I could pretend to was when I heard the Law laid on both sides to judge which was right."8

Even those colonial lawyers and judges who sought to keep current with English practice found a difficult time of it. Few published reports of decisions existed in the colonies; law libraries containing English reports were few and incomplete; English precedents were irregularly followed and given uneven weight. ${ }^{9}$ English emphasis on the technicalities of pleading in the seventeenth century compounded the difficulty of adhering to English law. In arcane English practice the most minor error in a writ rendered it defective and invalidated the claim; such practice required thorough mastery of the writ system. While some colonial lawyers undoubtedly became experts in the intricacies of the writ system, ${ }^{10}$ others distinguished between formal English "law" and "reason," "equity," or "justice."11 Alexander Hamilton noted that it was the practice in eighteenth century New York to "attend to" reported English decisions, but to reject them "where the injustices of them could be pointed out."12

The most detailed study of prerevolutionary law in America presently available, William Nelson's analysis of Massachusetts,

${ }^{6}$ C. Bell, The Bench and Bar of New Hampshire 40 (1894).

${ }^{7}$ Quoted in D. Boorstin, supra note 4, at 201.

${ }^{8}$ Quoted in 1 Legal Papers of John Adams xli (L. Wroth \& H. Zobel eds. 1965).

${ }^{9}$ See D. Boorstin, supra note 4, at 199; G. Wood, The Creation of the American REPUBLIC 1776-1787, at 296-97 (1969).

${ }^{10}$ See, e.g., J. Smith \& P. Crowl, Court Records of Prince Georges County, MARYLAND 1696-1699 (1964).

11 G. WOOD, supra note 9, at 298-99.

12 Quoted in 1 The Law Practice of Alexander Hamilton 51 (J. Goebel ed. 1964). See. D. Boorstin, supra note 4, at 200-01; G. Wood, supra note 9, at 297-99. 
finds a strong correlation between consensual social attitudes and common law practices. Massachusetts, Nelson argues, was for much of its colonial history unified in the belief that a stable, hierarchical, "christian" social order deserved perpetuation..$^{13}$ Law was consciously employed in numerous ways in Massachusetts to perpetuate such an order. Technicalities of pleading were preserved if they corresponded to meaningful technicalities of life: one could be thrown out of court, for example, if one called a yeoman a "laborer" or a gentleman a "yeoman."14 But technicalities would not be tolerated if they offended a communal sense of justice. "[I]f one is under obligation from the ties of natural justice to pay another money and neglects to do it," Judge Edmund Trowbridge announced in 1772, "the law gives the sufferer an action on the case ...." "[M]ere justice \&. equity" were "sufficient foundation" to bring an action. ${ }^{15}$ Overly voracious economic individualism, Nelson maintains, was perceived as undermining social stability; consequently Massachusetts courts sought to compensate victims of shrewd or unscrupulous business practices. Contract law in prerevolutionary Massachusetts, according to Nelson, "probably furthered ethical unity and stability in the allocation of wealth and status at the expense of economic efficiency." 16

While it helped perpetuate social and economic stability, the common law in Massachusetts was also used to promote morality and religiosity, primarily through public prosecution of "immoral" sexual offenses. Fornication that resulted in the birth of illegitimate children was punished regardless of whether the offenders subsequently married; in nearly all cases the party prosecuted was the woman. ${ }^{17}$ Drunkenness, blasphemy, "spreading falsehoods," and being a "common scold" were also indictable criminal offenses. ${ }^{18}$ Punishment for these crimes-normally a fine coupled with a whipping or some similar reprimand ${ }^{19}$-was designed to hold the offender up to public censure. Imprisonment was rare and "criminals" were drawn from all strata of

${ }^{13}$ See generally W. Neison, Americanization of the Common Law (1975).

${ }^{14}$ Id. 75-76.

15 Palfrey v. Palfrey, in W. Cushing, Notes of Cases Decided in the Superior and Supreme Judicial Courts of Massachusetrs 1772-1789, at 1, 92, 98-99, quoted in W. NeLSON, supra note 13 , at 55 .

${ }_{16}$ W. Nelson, supra note 13 , at 62.

${ }^{17}$ Id. 37-38.

${ }^{18}$ Id. 38-39.

${ }^{19}$ Id. 15. 
society. ${ }^{20}$ The primary purpose of the criminal law appears to have been the enforcement of community standards of morality. Civil suits for defamation, fraud, malicious prosecution, and the recovery of unpaid debts served a similar function. Creditors were awarded extensive remedies, in Nelson's view, not because of their political power but because their cause was regarded as just, and the evil of which they complained-failure to discharge a financial obligation-was considered especially pernicious. ${ }^{21}$

A final suggestive finding of Nelson's is Massachusetts' efforts to limit the lawmaking power of judges. The numerous informal powers of judges and the infrequent availability of legal sources fostered judicial discretion. Massachusetts sought to limit that discretion either by emphasizing adherence to precedent or by using juries as lawmakers as well as factfinders. ${ }^{22}$ The second device was probably more effective than the first because judges often misread, ignored, or were not aware of English decisions. Except for certain rules of evidence, juries had almost unlimited discretion to ignore judicial instructions and "find the law" themselves. ${ }^{23}$ Their decisions could be based on local custom even if it departed from common law rules. Jury decisions did not bind other juries, allowing room for individual equities to enter into a case. Judges often gave instructions to juries seriatim, inviting a choice among conflicting views of a controversy. Motions seeking appeal from jury verdicts were rarely granted. ${ }^{24}$

In sum, Nelson maintains that Massachusetts colonists "freely received the common law of England as the basis of their jurisprudence but simultaneously reserved the unfettered right to reject whatever parts of that law were inconsistent with their own views of justice and morality or with their own needs and circumstances."25 If Nelson's analysis is sound, "law" in colonial Massachusetts seems to have been not only indistinguishable from dominant social attitudes but localistic and possibly even "democratic." The common law appears to have been less a tool of elites than a reflection of widely held views, albeit views that served to perpetuate a stable and stratified social order. An older

\footnotetext{
${ }^{20} I d .40$.

${ }^{21}$ Id. 44-45.

${ }^{22}$ Id. 20.

${ }^{23}$ Id. $3,28$.

${ }^{24} I d .27$.

${ }^{25} \mathrm{Id} .30$.
} 
English view of law as a realm of mysteries interpreted by a trained elite and handed down to a complaisant populace ${ }^{26}$ seems to have been altered, at least in Massachusetts, by the realities of colonial life.

Systematic studies of whether other colonies conformed to the pattern of Massachusetts in their use of law and legal institutions are lacking. Although important ideological differences and settlement patterns distinguished the colonies, features similar to those Nelson identifies as having influenced the development of common law in Massachusetts were present in each. Every colony suffered a shortage of trained lawyers and judges; no colony possessed an abundance of English source materials; each was isolated from Europe and made up of communities linked to each other only by rudimentary transportation; in none was colonial government (as opposed to local government) an omnipresent force. ${ }^{27}$ In all the colonies judges performed legislative and administrative functions, in all those for which evidence is available they decided cases by appeal to equitable considerations as well as to English doctrines, and in all they reserved the right to disregard common law rules when they were unsuited to the American environment. Hence it is not unlikely that an association of common law with currently dominant social attitudes and values took place throughout the colonies, although the substantive content of common law doctrines, and of social attitudes as well, varied from colony to colony ${ }^{28}$ The critical unanswered question about colonial common law is whose values it perpetuated. That question can be answered only by further studies of individual colonies. Whatever the answer to that question, a conventional notion of common law as a formal entity which can be understood apart from its social and intellectual context will likely have to be abandoned.

\section{B. The Impact of Natural Rights Thought and a Written Constitution}

Environmental differences between England and America became apparent immediately to settlers in the New World, lead(1955).

${ }^{26}$ See generally J. Gough, Fundamental Law in Enguish Constrtutional History

${ }^{27}$ See generally D. Boorstin, supra note 4; R. Hofstadter, America at 1750: A SOCial PoRTRait (1971).

${ }^{28}$ See W. Nelson, supra note 13 , at 3. 
ing to the frank modification of English common law doctrines, as in the application of common law dower rights to uncultivated American lands. ${ }^{29}$ It was ideology, however, more than geography, that ultimately produced the rift between England and its American colonies. The American Revolution was in part the product of natural rights theory. In the 1760's England suddenly sought to modify colonial practices that it had long tolerated. In response to attempted modifications, the colonists defined their practices as grounded in inalienable rights, denied the authority of Parliament to usurp such rights, and eventually went to war to secure the ancient rights and liberties of Englishmen. ${ }^{30}$ The colonists drew mainly on three sources in asserting their rights: the legacy of British constitutional history, the charters of individual colonies, and the philosophical insights of Enlightenment theoreticians. ${ }^{31}$ Once they achieved independence, colonial leaders set out to create a governmental structure consistent with natural rights thought.

One of the intriguing questions about the American Revolution is why radical versions of natural rights thought found such widespread acceptance in America, so that a society with comparatively little economic discontent or social unrest became a seedbed of subversion and treason in the name of liberty. The importance of early eighteenth century English radicalism in shaping the perspective of American revolutionaries has been documented; ${ }^{32}$ how did views marginal in England come to be dominant in America? One possibility is the different institutional structure of government in the colonies. By the mideighteenth century Americans were accustomed to a much

${ }^{29}$ Id. 9.

${ }^{30}$ See generally B. Bailyn, The Ideological Origins of the American Revolution (1967); E. Morgan, The Birth of the Republic (1956).

${ }^{31}$ See generally B. BAILXN, supra note 30.

${ }^{32}$ Id. 34-54. A group of English writers and politicians waged a relentless, scathing attack on the powers and prerogatives of the King's ministers. The English radicals feared the growth of executive power at the expense of Parliament and accused the King's ministers of manipulating members of Parliament by bribery, extravagant favors and pensions, preferment, and the bestowal of lucrative offices upon them. The radicals believed that the ministry, through its lackeys in Parliament, levied taxes upon the people to support its drive for power and enhance its ability to manipulate and control Parliament, thereby drawing all power unto itself. They charged that the ministry maintained a standing army ostensibly to protect the public but in fact to strengthen the ministry's domination. Id. Although these ardent oppositionists achieved little popular support in their own time in England, their writings were enormously influential among the American colonists. Id. 51 . 
greater freedom from governmental interference than their counterparts in England. For the colonists Parliament, the Privy Council, and the Crown were remote bodies; colonial governors were often mere functionaries; colonial assemblies reflected the parochial interests of their constituencies. The notion of autonomy from governmental control was part of the reality of the American experience; in this context talk of inalienable rights against the state was not so revolutionary. ${ }^{33}$

Other contributing factors may have been the identification of America with newness, exploration, and freedom from the European past; the generally secular character of American settlements by the Revolution, which made Enlightenment ideas about the primacy of man palatable; the fact that American growth occurred after the Glorious Revolution's reduction of the power of the monarchy and articulation of ideas that were to become the foundations of natural rights theory in America. ${ }^{34}$ Whatever the explanation, the idea of natural rights gained a foothold in America and became a self-fulfilling prophecy as Great Britain sought to tighten her administration of the colonies in the 1760's and 1770's. In all government lay the seeds of tyranny, as the Stamp Act, the Sugar Act, and the Boston Port Act demonstrated. The people could not expect full protection of their liberties from government officials; officeholding bred corruption and the coveting of power..$^{35}$ The only way to protect the inalienable rights of the people was to record those rights in writing. The term "constitution," which had traditionally referred to the corpus or general framework of British laws and institutions, took on a new meaning. In eighteenth century American political thought "constitution" came to refer to a body of fundamental principles, extracted from human experience, which, in written form, set the limits of governmental

${ }^{33}$ E. Morgan, supra note 30 , at 8-12.

${ }^{34}$ See, e.g., J. Locke, The Second Treatise of Civil Government, in Two TREatises of Government 121-247 (T. Cook ed. 1947). See generally C. Becker, The Declaration of INDEPENDENCE (1922).

${ }^{35}$ The influence of English radicalism was especially felt in this regard. See note 32 supra. The colonists had read the claims of English radicals that the King's ministers were grasping for power and corrupting the legislature, all to the detriment of English liberties and the English constitution. Suddenly in the 1760's England began to impose controls on the colonists, including taxes, and decided to maintain a standing army in North America. Many Americans viewed these controls with great alarm, especially in light of their reading of the English radicals. The colonists feared that such measures were part of a conspiracy to deprive them of their liberties. B. BAILYN, supra note 30 . 
power. Older charters of rights and liberties for individual colonies, originally conceived as general references rather than guarantees of fundamental political rights, were reinterpreted as efforts to codify first principles of government. The permanent preservation of rights in a written constitution came to be regarded as a necessary bulwark against tyranny; the unwritten British constitution would not suffice. ${ }^{36}$

The idea of a written constitution imparted a new dimension to law in America. Law was, in addition to a manifestation of current social attitudes, a body of universal principles. The very universality of those principles gave them permanence; hence law could not change completely with time and circumstance, but could change only in conformity with the mandates of the Constitution. A Pennsylvanian declared in 1776 that "[m]en entrusted with the formation of civil constitutions should remember that they are painting for eternity: that the smallest defect or redundancy in the system they frame may prove the destruction of millions." 37 Among the difficulties posed by a constitution was its effect on the common law heritage of 'Americans. Would a constitution supplant the common law, or would it be superimposed upon the common law? Who was to determine the application of universal principles to concrete situations? How were areas of American life not governed by specific constitutional provisions to be treated?

Despite the momentousness of these questions, the revolutionary generation in America gave them little attention. The authors of the Declaration of Independence and the framers of the Constitution were concerned primarily with declaring certain principles of natural rights to be "self-evident" and with effectuating their theory of popular sovereignty. They were apparently satisfied with letting the common law continue to develop independent of constitutional control and with codifying a tripartite system of governmental powers without deciding which of the three branches of government would have final authority to interpret what had been codified. ${ }^{38}$

${ }^{36}$ Id. 175-89; G. WooD, supra note 9, at 259-68.

37 Anonymous, The Genuine Principles of the Ancient Saxon or English Constitution 34 (1776) (emphasis in original), quoted in B. BAILXN, supra note 30 , at 184.

${ }^{38}$ See Levy, Judicial Review, History, and Democracy: An Introduction, in Judrcial Review and the Supreme Court 1-8 (L. Leviy ed. 1967) [hereinafter cited as Judicial Review]; Thayer, The Origin and Scope of the American Doctrine of Constitutional Law, in id. 


\section{The Emergence of the Judiciary in the Early Nineteenth Century}

Colonial judges were among the officials whose peremptory treatment of liberties natural rights theorists feared. Little in the colonial experience suggested that the judiciary would emerge eventually as the chief institutional protector of civil liberties and the primary interpreter of the Constitution. The status of judges in prerevolutionary Massachusetts was probably representative: judges were generally prominent men without legal training whose power to differ from community sentiment was sharply curtailed by the community. ${ }^{39}$ The possibility of judicial discretion, ${ }^{40}$ although recognized, was not applauded. ${ }^{41}$ The courts, a commentator noted five years after the Declaration of Independence, "must take the law as it is, and by all due and proper means execute it, without any pretense to judge if it's right or wrong." 42 Allowing judges to set aside a law, James Madison wrote in 1788, "makes the Judiciary Department paramount in fact to the Legislature, which was never intended and can never be proper." 43

Yet in the late eighteenth and early nineteenth centuries the judiciary emerged as a creative lawmaking force. One factor explaining this development was the ambiguous status of legislative bodies in a republic. Americans seemed to regard state legislatures as autonomous but manifested uneasiness about limitless powers in Congress. A major purpose of a written constitution was to place permanent checks on governmental power; if Congress alone could determine the meaning of the Constitution,

43-63. Some framers and supporters of the new Constitution, most notably Alexander Hamilton, urged that the courts have the authority to interpret the Constitution, noting that state courts already exercised the power of judicial review over state legislation. The Federalist Nos. 78, 80, 81 (B. Wright ed. 1961) (A. Hamilton); Levy explains Hamilton's support for judicial review in The Federalist as a political tactic in the struggle for ratification rather than as an expression of the framers' intent. Judicial Review, supra, at 6.

${ }^{39}$ W. NELSON, supra note 13 , at 32-33.

40 "Judicial discretion" in this context refers to the freedom of judges to decide cases in accordance with their own predilections rather than as indicated by precedent, statute, or the values of the community. See generally Dworkin, The Model of Rules, $35 \mathrm{U}$. CHI. L. REv. 14 (1967); Raz, Legal Principles and the Limits of Law, 81 YAle L.J. 823, 842-54 (1972).

${ }^{41}$ G. Wood, supra note 9 , at 298.

42 Trenton Gazette, Apr. 18, 1781, quoted in G. Wood, supra note 9, at 302.

43 James Madison's Observations on Thomas Jefferson's Draft of a Constitution for Virginia, Oct., 1788, in 6 The Papers of Thomas Jefrerson 315 (J. Boyd ed. 1952) (footnote omitted). 
that purpose might be defeated. As for the Executive, no rightthinking American patriot was prepared to invest unlimited discretionary power in an office that bore trappings of monarchy. From its origins American constitutionalism differed from the British model in rejecting the notion of absolute sovereignty in any branch of government. Government actions were to conform to the principles of the Constitution, which were not identified with any group save the people at large. ${ }^{44}$

In the context of American constitutionalism a theory of judicial interpretation first began to develop. Attempts to make "law" synonymous with written codes invariably run into problems of coverage: The language of constitutions or statutes cannot anticipate every contingency. In novel contexts some interpretation of language is required. In the framers' debates in the Constitutional Convention, and in the earliest years under the Constitution, the possibility that Congress would act as chief interpreter was given serious consideration. The argument for congressional interpretation rested on the assumption that law is the will of the sovereign and the judiciary is bound to follow it; because Congress represents the sovereign people, it should declare their will. This argument ultimately foundered on the belief that law was bounded by the natural rights principles embodied in the Constitution, which even the will of the legislature could not contravene. Yet appeals to the Constitution were meaningless unless someone interpreted the document; if the legislature could not, who could? John Marshall seized upon this dilemma to develop the concept of independent judicial review in Marbury $v$. Madison. ${ }^{45}$

Marshall's argument in Marbury intertwined three propositions: First, the Constitution is the supreme source of law in America, to which the legislature is subordinate; second, ultimate construction of the Constitution by a legislature runs counter to the first proposition, because it would make constitutional principles synonymous with the legislative will; third, the proper interpreter of the Constitution in situations in which it clashes with legislative acts is the judiciary, because the judiciary is empowered only to declare the law, not to make it. Hence the true meaning of the Constitution is ascertainable only through

${ }^{44}$ But see C. BEARD, AN ECONOMIC INTERPRETATION OF THE Constitution of the United States (1913).

455 U.S. (I Cranch) 137 (1803). 
judicial interpretation. ${ }^{46}$ Once Americans had decided to have a constitution with a tripartite governmental structure, Marshall's argument implied, they had necessarily decided to have an independent judiciary, because the Constitution was supreme and yet its coverage was not preordained, and judges could be counted on to be disinterested expositors of constitutional principles.

Marshall's position was not unassailable. Adherence to a declaratory theory of the judicial function did not eliminate the problem of judicial discretion. ${ }^{47}$ A group of thinkers as convinced of man's susceptibility to corruption and tyranny as the revolutionary generation was not likely to be sanguine about judicial disinterestedness. ${ }^{48}$ Interpretive powers in the judiciary secured a foothold in America not only because of Marshall's ingenuity but because of changes in the social and economic climate of the nation. In the years following the framing of the Constitution social and economic developments helped break down the patterns of stability, order, interdependence, and hierarchical social organization that had marked colonial settlements. The expansion and transformation of the economy (especially in its transportation sector), the decline of organized religion, the growth and diffusion of population, the development of a more heterogeneous ethnic base, the lure of vacant land, and the emergence of literature deemphasizing social obligations and emphasizing individual freedoms and accomplishments, combined to disrupt the communal homogeneity and solidarity of prerevolutionary America. ${ }^{49}$ As the American environment changed, law became more of a vehicle for facilitating individual action and accomplishment. ${ }^{50}$

For reasons that have not yet been explained fully ${ }^{51}$ the judiciary, at both the federal and state levels and with respect to supra.

${ }^{46} I d$. at 176-79. Hamilton expounded these principles in The Federalist. Note 38

${ }^{47}$ See generally sources cited note 40 supra.

48 For a useful survey of the variety of attitudes on judicial review at the time of the framing of the Constitution, see Judicial Review, supra note 38.

49 The following sources discuss specific aspects of early nineteenth century American culture: G. Taylor, The Transportation Revolution (1951); T. Smith, Revivalism and Social Reform (1957); R. Wade, The Urban Frontier (1959); H. Smith, Virgin Land (1950); A. KaUl, The American Vision (1963).

${ }^{50}$ See generally J. Hurst, The Growth of American Law (1950); W. NeLson, supra note 13.

${ }^{51}$ But see Horwitz, The Emergence of an Instrumental Conception of American Law, 1780-1820, in Law in American History (5 Perspectives in American History) 287 (D. Fleming \& B. Bailyn eds. 1971) [hereinafter cited as LAW IN AMERICAN History]. 
both constitutional and common law issues, came in the early nineteenth century to assume a posture of promoting social welfare by fostering individual entrepreneurial activity. In the process judges expanded their interpretive powers. By the close of Chief Justice Marshall's tenure in 1835 the Supreme Court had emerged as a consistent, if not constant, supporter of the right to unrestricted use and enjoyment of one's property; ${ }^{52}$ it also had emerged as a formidable lawmaking force. Meanwhile local community control of judicial decisionmaking diminished; judges began to reserve the law-declaring function for themselves in the areas of riparian rights, admiralty, and damages, ${ }^{53}$ among others, and to articulate their decisions in terms of principles of wider applicability. ${ }^{54}$ That Americans tolerated this aggrandizement of judicial power suggests that judicial decisions were furthering values that had come into prominence, such as freedom and predictability in the conduct of individual affairs, and that other values such as community solidarity, which had served as checks on judicial discretion in colonial America, had declined in significance. The breadth of the judiciary's new constituency remains a matter of historical debate. ${ }^{55} \mathrm{It}$ is clear, however, that in an atmosphere of increasing deemphasis of community solidarity and a growing emphasis on individual initiative judges solidified their position as the primary interpreters of the Constitution and the leading architects of changing common law doctrines. With the emergence of the judiciary in this dual capacity an indigenous American jurisprudence was born.

52 The Court's protection of private property rights was achieved primarily by an expansion of the scope of the Constitution's contract clause. See, e.g., Fletcher v. Peck, 10 U.S. (6 Cranch) 87 (1810); New Jersey v. Wilson, 11 U.S. (7 Cranch) 164 (1812); Sturges v. Crowninshield, 17 U.S. 70, 7 Wheat. 122 (1819); Trustees of Dartmouth College v. Woodward, 17 U.S. 250, 7 Wheat. 518 (1819). For a discussion of the Marshall Court's protection of private property rights through the contract clause, see $B$. Wright, The Contract Clause of the Constiturton 3-53 (1938). A sophisticated treatment of Marshall's theory of property rights is found in R. FAULKNER, ThE JURISPRUDENCE OF JOHN MARSHALL (1968).

${ }^{53}$ These areas are discussed briefly in Horwitz, supra note 51 , at 289, 322-24.

54 W. NELSON, supra note 13, at 117-64; Horwitz, The Transformation in the Conception of Property in American Law 1780-1860, 40 U. CHI. L. Rev. 248 (1973).

${ }^{55}$ See W. Nelson, supra note 13 , at 165-74. The pervasiveness of entrepreneurial values in the population at large in the early nineteenth century, see I. WyLlIE, THE SELF-MAdE MAN IN AMERICA (1954), suggests that the judiciary may have been responding to widely held attitudes. It is possible, however, that the enhanced role of the judiciary is attributable to the judges' responsiveness to the needs of an economic elite. See L. Friedman, A History of American Law 99-100 (1973). 


\section{The Creation of an American Jurisprudence}

By the second decade of the nineteenth century the distinctive features of American jurisprudence were established. The colonial experience had produced an impression of common law more as a repository of social attitudes than as a mysterious body of rules. Notwithstanding a view of judging that assumed that "law" was sufficiently finite to be "discovered," Americans had not equated law with a set of rules that compelled obedience whether reasonable and just or not. The "brooding omnipresence" of law in America was essentially the omnipresence of natural rights, the "higher law" to which one could appeal. The American colonists continually had revised or abandoned English common law doctrines if they were inequitable or inefficient; the colonists had come to believe that law was meaningless apart from its social context.

If the years prior to the Revolution had nurtured a distinctively American attitude toward law, the revolutionary generation refined this attitude by giving law another dimension. By introducing a supreme, permanent source of law, the framers of the Constitution checked any jurisprudential inclination to conform law entirely to dominant social attitudes. Certain legal principles, the Constitution suggested, were to be virtually immune from change. Future events and ideas might alter the meaning of law only up to a point; certain rights, powers, privileges, and limitations were unalterable. Superimposed upon a fluid and diverse body of common law in America was a more rigid body of constitutional law.

But even the Constitution was not free from change. The generality of its language and the incompleteness of its coverage, in short, the need for its interpretation, meant that contemporary social attitudes could affect its meaning. With the origins of an American jurisprudence came a complex relationship between common law, ${ }^{56}$ constitutional law, and changing social perceptions. The Constitution set limits on the permissible range of federal and state activity. For example, states could not interfere with previous contracts between private parties $^{57}$ and the federal government could not try persons twice for the same 
offense. ${ }^{58}$ At the same time, the Constitution apparently left a vast amount of activity free of its coverage, allowing a considerable body of nonconstitutional law to develop.

The above developments created a continuing possibility of tension between newly created nonconstitutional doctrines, reflecting changing social attitudes, and constitutional principles. In areas apparently untouched by constitutional law a network of common law relationships emerged; but when a common law or legislative concept or doctrine, or a private practice, took on sufficient social significance, it became a matter of "constitutional" concern. Competitive transportation franchises, neither prohibited nor permitted by the language of the Constitution, were eventually attacked as inconsistent with the contract clause, and the Supreme Court was forced to settle the matter in favor of competition. ${ }^{59}$ The institution of slavery borrowed a number of common law property doctrines to organize its relationships; eventually those doctrines were judged to reflect constitutional rights violated by states unsympathetic to slavery or, alternatively, judged to offend the civil rights of blacks. Thus the property rights of slaveholders ${ }^{60}$ and the citizenship status of freed slaves $^{61}$ became questions of constitutional law. The domain of common law, which mostly had developed independently of constitutional law, nevertheless became a recurrent source of constitutional issues; conversely, the resolution of constitutional issues regularly had common law implications.

The principal institution for resolution of the tension between the common law and the Constitution came to be the judiciary. Doctrines or legal entities that had ancient common law origins, such as eminent domain or the corporation, became revitalized in nineteenth century America and eventually were given constitutional sanction by judges. ${ }^{62}$ In addition,

${ }^{58}$ U.S. ConsT. amend. V.

${ }^{59}$ In Charles River Bridge v. Warren Bridge Co., 36 U.S. 341, 11 Pet. 420 (1837), the Massachusetts legislature had given plaintiffs a franchise to build a toll bridge over the Charles River. Forty-three years later, the legislature granted a franchise to another corporation to build a bridge (without tolls) over the same river. The first corporation suffered a loss of revenue, but the Court rejected its claim that the granting of the second franchise violated the contract clause.

${ }^{60}$ E.g., Strader v. Graham, 51 U.S. (10 How.) 82 (1851).

${ }^{61}$ E.g., Dred Scott v. Sandford, 60 U.S. (19 How.) 393 (1857). See also text accompanying notes $118-20$ infra.

62 On James Kent's contributions to the development of eminent domain, see generally J. Horton, James Kent: A Study in Conservatism (1939); on Joseph Story's role 
the nineteenth century judiciary became the chief creator of constitutional limitations on private conduct. The same judges who pioneered in harmonizing innovative common law doctrines with the Constitution-Joseph Story, Roger Taney, Lemuel Shaw -also stressed the implications flowing from the Constitution's recognition of slavery as a legitimate institution. ${ }^{63}$

The indigenous character of American jurisprudence is fully discernible by the middle of the nineteenth century. A uniquely broad definition of "common law," a reverence for natural rights principles as embodied in the Constitution, and a high tolerance for judicial lawmaking in nonconstitutional and constitutional contexts, are evident. Major themes of American legal history can be viewed as outgrowths of these central features of American jurisprudence.

Three such themes will be traced in the following section of this Article. The first is the presence of transient constitutional "doctrines," analogous to the doctrinal creations of common law courts. The notion that the Constitution, supposedly a source of permanent principles, can be glossed by judges, and the evidence that such glosses rise and fall in prominence, testify to the close interplay in American jurisprudence of changing social mores, common law adjudication, and constitutional interpretation.

A second theme is the competitive interaction of constitutional and nonconstitutional law, particularly in the late nineteenth and twentieth centuries when statutory and administrative lawmaking proliferated, causing a redefinition of "common law" adjudication. Judges have continued to play a creative role as lawmakers despite the plethora of statutory and administrative "laws" that have emerged since the Civil War. The role of the judiciary as a constitutionalizing agent, charged with the simultaneous duties of conforming changing social attitudes and practices to constitutional principles and of accommodating the Constitution's coverage to emerging values, has been maintained. But the much larger body of nonconstitutional law in modern America and the increased presence of alternative law-

in the emergence of the corporation, see G. Dunne, Justice Joseph Story and the Rise of THE Supreme Court (1970).

${ }^{63}$ A thorough account of Story's and Shaw's ambivalence toward the slavery issue is R. Cover, Justice Accused (1975). For Taney's involvement with the issue, see C. Swisher, Roger B. Taney (1935); C. Swisher, The Taney Period 1836-1864 (1974) [hereinafter cited as The Taney Period]. 
making institutions has changed the process of constitutionalization for the judiciary and complicated the relationship between constitutional and nonconstitutional law.

A third theme is the relationship between broad changes in juristic perspectives and changing conceptions of legal scholarship, with special reference to lawyer historians' successive definitions of "legal history." Analysis of the interplay of constitutional and nonconstitutional law in American history reveals the presence, in different time periods, of dominant juristic attitudes which express distinctive perspectives on law and legal institutions. At some times in American history such perspectives insist on a wide ambit for constitutional principles, so that nonconstitutional law is perceived as pregnant with potential constitutional issues and the judiciary is invited to apply constitutional principles to a wide variety of ordinary legal relationships. In other periods the dominant perspective reserves the Constitution for a limited number of issues, and active experimentation in nonconstitutional areas is encouraged. In some periods influential jurists perceive a rigid analytical separation between constitutional and nonconstitutional law; in others constitutional and nonconstitutional lawmaking are thought of as discrete parts of an integrated legal process. The same perspectives that produce one or another of the above emphases affect the subjects and methodologies of legal scholarship.

The "path" of American jurisprudence, as traced in this Article, consists of selected thematic corollaries to the proposition that unique attitudes about law and the judiciary emerged in nineteenth century America. In addition to the themes upon which the Article focuses, one broader characteristic can be noted. Since the "creation" of an American jurisprudence, American lawyers and legal scholars have not thought about law in the same manner as have their English counterparts with a similar common law heritage. The close association of "law" with current social attitudes and the decisions of an activist, "lawmaking" judiciary has not only immersed American judges in contemporary social issues, but has made a rigid separation of law from politics appear artificial to Americans. The identification of common law with currently dominant social attitudes and of constitutional law with natural rights has interfused "law" and "justice" for Americans. A definition of law as merely a body of rules appears unrealistic in the American context. However much American jurists have been interested in portraying law as a 
"science" with governing universal axioms and concepts, ${ }^{64}$ the effort has never entirely succeeded. From the nineteenth century to the present, "policy," "morals," and "law" have been intertwined in American jurisprudence, despite juristic attempts to separate them.

\section{Some Themes of American Jurisprudence}

\section{A. The Rise and Fall of Constitutional Doctrines}

One of the characteristics of a jurisprudence that creates a permanent source of law in a constitution but requires that the source be continually interpreted in light of changing social perceptions is the appearance of fluctuating trends in constitutional interpretation. A manifestation of such trends is the changing status of various constitutional "doctrines," or judicially created glosses on broad language in the Constitution. Constitutional doctrines represent judicial efforts to conform constitutional law to dominant modes of thought, thereby reinforcing public confidence in the judiciary as a constitutionalizing agent. Three variables affect the current status of constitutional doctrines: the stature of particular social values at various times in American history, the textual support (or lack thereof) for a particular value as a constitutional "right," and the current state of public confidence in the judiciary as a lawmaking force. Two constitutional doctrines, "liberty of contract" and "privacy," serve as illustrations.

\section{Liberty of Contract}

Prior to the Civil War constitutional protection of entrepreneurial activity from governmental interference was secured primarily through the contract clause of the Constitution..$^{65} \mathrm{En}$ trepreneurs were not entirely free from governmental regulation despite that clause. Most economic ventures required state subsidization, and in chartering franchises states reserved the power to amend a charter's terms, thereby avoiding a contract clause challenge. State/private economic partnerships and state regulation of the economy were common, if controversial,

${ }^{64}$ There have been times when this interest has been considerable. See note 178 infra. See generally White, From Sociological Jurisprudence to Realism: Jurisprudence and Social Change in Early Twentieth Century America, 58 VA. L. Rev. 999 (1972).

${ }^{65}$ See B. WRIGHT, supra note 52, at 27-88. 
notions. ${ }^{66}$ After 1860 , however, the purchasing power of private individuals increased markedly, entrepreneurs undertook ventures without public capital, state governments reduced their regulatory operations, and theories of economic individualism rose in popularity. By the last decades of the nineteenth century massive enterprises had appeared which were accustomed to doing business free from any governmental regulation.

Social, intellectual, and economic trends increasingly favored unregulated private activity. The fourteenth amendment's due process clause apparently codified "liberty" as a paramount value, and the clause was interpreted to protect corporations. ${ }^{67}$ In this atmosphere treatise writers interpreted "liberty" in the due process clause to encompass freedom to "contract"- to buy and sell one's services on the terms for which one bargained. ${ }^{68}$ By the late nineteenth century a climate favorable to incorporation of antiregulationist economic theories into the Constitution had developed. First the state ${ }^{69}$ and then the federal ${ }^{70}$ judiciary announced as a principle of constitutional law that no state could pass legislation that interfered with the right of an individual to contract freely.

Liberty of contract undoubtedly served the interests of enterprises that were in strong bargaining positions and wanted to maintain a predictable and modest level of compensation for their employees. The doctrine did not assure that their expenditures for wages would remain constant, considering that the market for employee services fluctuated, but it allowed them to hire employees at the "going rate" regardless of its inequities. In the late nineteenth century, however, as industrial enterprise matured and the population of the United States grew and di-

${ }^{66}$ See generally O. Handin \& M. Handlin, Commonwealth (1969); 2 A. Howard, Commentaries on the Constitution of Virginia 1126-30 (1974); J. Hurst, Law and the Conditions of Freedom in the Nineteenth-Century United States (1956).

${ }^{67}$ Santa Clara County v. Southern Pac. R.R., 118 U.S. 394 (I886). On economic life in the late nineteenth century, see E. KIRKLAND, INDUSTRY Comes of AGE (1961).

${ }^{68}$ On the juristic origins of liberty of contract, see C. JACOBS, LAW WRITERS AND THE Courts (1954).

${ }^{69}$ E.g., Godcharles \& Co. v. Wigeman, 113 Pa. 431, 6 A. 354 (1886); State v. Goodwill, 33 W. Va. 179, 10 S.E. 285 (1889); Ritchie v. People, 155 Ill. 98,40 N.E. 454 (1895).

${ }^{70}$ Missouri Pac. Ry. v. Nebraska, 164 U.S. 403 (1896), was the first case in which the Supreme Court invalidated a state statute through use of the due process clause in an economic context. Allgeyer v. Louisiana, 165 U.S. 578 (1897), was the first case in which the Court explicitly recognized a fourteenth amendment "liberty" to contract. Id. at 589 . 
versified, unregulated industrialism produced an underclass of subsistence workers whose existence became a matter of public concern. Disease, violence, and poverty were discernible adjuncts to industrial growth. Gaps between the income levels and life styles of the "captains of industry" and industrial workers offended egalitarian traditions. Efforts to alleviate the casualities of industrialism were undertaken, initially by private agencies and eventually by the states in the form of wage and hour legislation. ${ }^{71}$ That legislation encountered the liberty of contract principle.

In passing upon the validity of state wage and hour legislation the judiciary confronted another example of dissonance between contemporary social trends and constitutional principles. Adherence to the liberty of contract doctrine would invalidate nearly any piece of social welfare legislation designed to confer benefits on persons who could not obtain those benefits in a free market; to invoke liberty of contract meant to oppose increasingly popular humanitarian views. On the other hand, validation of social welfare statutes emasculated the principle of economic liberty. For a time the Supreme Court clung to freedom of contract. ${ }^{72}$ After severe academic criticism, however, ${ }^{73}$ the Court decided that liberty of contract was only a doctrine, not a principle of fundamental law, and that having been "interpreted" into being, the doctrine could be interpreted into obscurity. ${ }^{74}$

In the process, however, the Supreme Court was forced temporarily to qualify its power as a constitutionalizing agent. The attack on liberty of contract stressed that the notion was a fiction, because true equality of bargaining power did not exist between the employers and employees of industrial America; that it was based on an economic philosophy unsupportable in twentieth century America; that in invoking liberty of contract judges were approving that philosophy; and that judges should

${ }^{71}$ Late nineteenth and early twentieth century perceptions of the costs of mature industrialism are described in R. BREMner, From the DePths (1956); S. Fine, Laissez FAtre AND THE General-Welfare State (1956).

${ }^{72}$ E.g., Adair v. United States, 208 U.S. 161 (1908); Adkins v. Children's Hosp., 261 U.S. 525 (1923), overruled, West Coast Hotel Co. v. Parrish, 300 U.S. 379 (1937).

${ }^{73}$ E.g., Pound, Liberty of Contract, 18 Yale L.J. 454 (1909).

${ }^{74}$ West Coast Hotel Co. v. Parrish, 300 U.S. 379 (1937). In that case Chief Justice Hughes, for the majority, said that "[t]he Constitution does not speak of freedom of contract. . . L Liberty under the Constitution is . . subject to the restraints of due process, and ... regulation which is reasonable in relation to its subject and is adopted in the interests of the community ...." Id. at 391. 
not read their social and economic views into the Constitution. ${ }^{75}$ Further judicial adherence to an outmoded idea would have revived the spectre of judicial tyranny. Implicit in the recognition of the judiciary as a constitutionalizing agent had been the assumption that judge-made glosses on the Constitution would reflect contemporary social attitudes, not the personal views of judges. Hence coincidentally with the attack on the liberty of contract doctrine came calls for a reduced judicial role in constitutional interpretation, in which the courts would assume a permissive stance toward legislative innovations. ${ }^{76}$ This stance assumed implicitly that the Constitution could accommodate legislative solutions to social problems if they were devised on a rational basis. In seeking to curtail the judiciary's power to scrutinize legislative solutions, critics wanted to oust judges from their position as the primary link between social change and constitutional principles. ${ }^{77}$

\section{Privacy}

Liberty of contract passed into oblivion after 1937, leaving the circumscribed constitutionalizing role for courts its unpopularity had helped foster. The manner in which the constitutional doctrine of privacy was announced and the doctrine's delayed arrival were functions of the persistence of a narrowly defined constitutionalizing role for the judiciary. The Supreme Court refused to give substantive content to the fourteenth amendment's due process clause throughout the 1940's, 1950's, and 1960 's, ${ }^{78}$ a refusal applauded by the commentators. ${ }^{79}$ The

${ }^{75}$ See Lochner v. New York, 198 U.S. 45, 74 (1905) (Holmes, J., dissenting).

${ }^{76}$ This was part of the message of Justice Holmes' dissent in Lochner:

This case is decided upon an economic theory which a large part of the country does not entertain. If it were a question whether I agreed with that theory, I should desire to study it further and long before making up my mind. But I do not conceive that to be my duty, because I strongly believe that my agreement or disagreement has nothing to do with the right of a majority to embody their opinions in law. . . The Fourteenth Amendment does not enact Mr. Herbert Spencer's Social Statics. $I d$. at 75 .

${ }^{77}$ In 1912 Theodore Roosevelt called for "the exercise of the referendum by the people themselves in a certain class of decisions of constitutional questions in which the courts decide against the power of the people to do elementary justice." 19 THE Works of Theodore RoOSEvelt 258 (H. Hagedorn ed. 1925).

${ }^{78}$ See, e.g., Olsen v. Nebraska, 313 U.S. 236 (1941); Lincoln Fed. Labor Union v. Northwestern Iron \& Metal Co., 335 U.S. 525 (1949); Day-Brite Lighting, Inc. v. Missouri, 342 U.S. 421 (1952).

${ }^{79}$ See, e.g., McCloskey, Economic Due Pracess and the Supreme Court: An Exhumation and Reburial, 1962 Sup. CT. Rev. 34. 
Court said in Ferguson v. Skrupa, ${ }^{80}$ "We have returned to the original constitutional proposition that courts do not substitute their social and economic beliefs for the judgment of legislative bodies ...." ${ }^{81}$ In the meantime, however, legislative solutions to social problems had proved to have some costs of their own. Legislatures could infringe individual rights as well as protect them; being a ward of the government could result in loss of one's freedom. ${ }^{82}$

One consequence of active government was increased governmental involvement in people's lives. Distribution of the benefits conferred by social welfare legislation, for example, required an administrative apparatus that supposedly needed a plethora of information about the program's beneficiaries. ${ }^{83}$ In numerous other respects twentieth century American civilization reduced one's opportunities for privacy. Sophisticated electronic devices made eavesdropping and wiretapping relatively easy tasks. The telephone, the camera, and the advent of mass media sharply reduced distances between oneself and one's neighbors. Urban living became an exercise in insulating oneself from crowds. The private lives of public figures and the extraordinary experiences of otherwise unknown persons became matters for commercial exploitation.

Despite the growing consciousness of the value of privacy in the twentieth century, "privacy" was slow to become a constitutionally protected "right." The delayed constitutionalization of privacy was in part a function of the early twentieth century contraction of the judiciary's constitutionalizing function. Academic and judicial criticism of "substantive" judging caused the

80372 U.S. 726 (1963).

${ }^{81}$ Id. at 730 .

${ }^{82}$ In the 1940's and '50's the Court was reluctant to upset restrictive legislation of any kind, except in the first amendment area. See, e.g., Board of Educ. v. Barnette, 319 U.S. 624 (1943); Thomas v. Collins, 323 U.S. 516 (1945). Cases like Skinner v. Oklahoma, 316 U.S. 535 (1942), invalidating an Oklahoma sterilization statute on equal protection grounds, were rare. But by the 1960's the Court had come to use the equal protection clause in a "substantive" manner, striking down legislative classifications that amounted to "invidious discrimination" against beneficiaries of government largesse. See, e.g., Shapiro v. Thompson, 394 U.S. 618 (1969).

${ }^{83}$ In some government programs, such as social security, participation (symbolized by a social security number) gave interested parties access to general information about the participant; in others, such as welfare, administrators were far more zealous in their quest for information, to the point of searching the homes of recipients to ensure that their qualifications for largesse were bona fide. See Parrish v. Civil Serv. Comm'n, 66 Cal. 2d 260, 425 P.2d 223, 57 Cal. Rptr. 623 (1967); Reich, Midnight Welfare Searches and the Social Securily Act, 72 YALE L.J. 1347 (1963). 
Supreme Court to assume a posture of deference toward legislative regulation of economic affairs after the 1930's; this tolerance was extended tacitly to regulation of noneconomic matters. If the federal government and the states could regulate hours and wages, why could they not regulate social activity? From the 1930's to the 1960's the answer was that they could within reasonable limits, ${ }^{84}$ with the sole exception of speech, which many justices felt the first amendment singled out for special protection. ${ }^{85}$

In this context the Connecticut birth control cases, ${ }^{86}$ which tested the constitutionality of a statute prohibiting the use of contraceptive devices by married persons, came before the Supreme Court. The Connecticut law, which conceivably justified searches of private homes to ensure that birth control was not being practiced, appeared not to infringe any constitutional rights then recognized by the Court. No right of privacy is mentioned in the Constitution, and the law seemed not to violate any constitutionally protected "liberties," because "liberty" in the fourteenth amendment had been stripped of most its substantive content. Yet the birth control cases were clearly substantive due process cases, although, of course, not explicitly so. As in the liberty of contract decisions before 1937, the Court was urged to give substantive meaning to "liberty" in the fourteenth amendment. The essential difference was that this time the meaning would not be an economic one.

Recognizing the substantive due process implications of the birth control cases, the Court in Griswold v. Connecticut ${ }^{87}$ took pains to dissociate itself from that position. "Overtones of some arguments," Justice Douglas wrote for the majority, "suggest that Lochner v. New York," a liberty of contract opinion, "should be our guide. But we decline that invitation .... We do not sit as a super-legislature to determine the wisdom, need, and propriety of laws that touch economic problems, business affairs, or social conditions. [The Connecticut law], however, operates directly on an intimate relation of husband and wife ..."88 That relationship was found worthy of constitutional protection be-

${ }^{84}$ United States v. Carolene Prods. Co., 304 U.S. 144 (1938).

${ }^{85}$ See note 82 supra.

${ }^{86}$ Poe v. Ullman, 367 U.S. 497 (1961); Griswold v. Connecticut, 381 U.S. 479 (1965).

${ }^{87} 381$ U.S. 479 (1965).

${ }^{88} 381$ U.S. at $481-82$ (citations omitted). 
cause the very idea that police could search the sacred precincts of marital bedrooms for telltale signs of the use of contraceptives is "repulsive." 89 The Court wanted to afford protection to "zones of privacy";90 but the constitutional basis of a "right" of privacy was never specified definitively. Justice Douglas could only identify "penumbras, formed by emanations" from specific guarantees in the Bill of Rights. ${ }^{91}$

The advent of the right of privacy demonstrates that when a contemporary value becomes sufficiently prominent it will receive constitutional recognition, but the form in which it is recognized will be determined not only by the Constitution's text but by current conceptions of the constitutionalizing function. The Griswold opinion was both ingenious and absurd: ingenious because Justice Douglas' reading of Bill of Rights provisions demonstrated that if privacy was not a right enumerated in the Constitution, it was arguably one of its core values; absurd because of the tortuous interpretation the Court endured to avoid the highly unpopular doctrine of substantive due process. ${ }^{92}$

\footnotetext{
${ }^{89} \mathrm{Id}$. at $485-86$.

${ }^{90} I d$. at 484 .

${ }^{91} \mathrm{Id}$.
}

92 The Court not only felt constrained in Griswold to deny that its holding resurrected the discredited due process analysis of an earlier time, see text accompanying notes 88-91 supra, it suggested, both in Griswold and in Roe v. Wade, 410 U.S. 113 (1973), that the right of privacy had long been protected implicitly by the Court. The Court seemed to suggest that its holdings in Griswold and Roe did not so much announce a "new" right of privacy as they added further dimensions to an implicitly recognized right. Thus in Griswold Justice Douglas cited, inter alia, NAACP v. Alabama, 357 U.S. 449 (1958); NAACP v. Button, 371 U.S. 415 (1963); and Schware v. Board of Bar Examiners, 353 U.S. 232 (1957), to argue that the Court had safeguarded privacy before in its protection of freedom of association. 381 U.S. at 483-84. He also pointed to the Court's decisions under the fourth and fifth amendments as examples of the Court's past recognition of the right to privacy. Id. at 484-85.

Justice Blackmun, in an effort to root the Roe decision firmly in the Court's prior cases, said:

The Constitution does not explicitly mention any right of privacy. In a line of decisions, however, going back perhaps as far as Union Pacific R. Co. $v$. Botsford, 141 U.S. 250, 251 (1891), the Court recognized that a right of personal privacy, or a guarantee of certain areas or zones of privacy, does exist under the Constitution. In varying contexts, the Court or individual Justices have, indeed, found at least the roots of that right in the First Amendment, Stanley v. Georgia, 394 U.S. 557, 564 (1969); in the Fourth and Fifth Amendments, Terry v. Ohio 392 U.S. 1, 8-9 (1968), Katz v. United States, 389 U.S. 347, 350 (1967), Boyd v. United States, 116 U.S. 616 (1886), . . in the penumbras of the Bill of Rights, Griswold v. Connecticut, 381 U.S., at 484-485; in the Ninth Amendment, id., at 486 (Goldberg, J, concurring); or in the concept of liberty guaranteed by the first section of the Fourteenth Amendment, see Meyer $v$. Nebraska, 262 U.S. 390, 399 (1923) . . . . [These decisions] make it clear that 
Seven years after Griswold the Court was still not prepared to make the right of privacy a "liberty," although it was prepared to free it from the marital relationship in the contraception context and include in it "the right of the individual, married or single, to be free from unwarranted governmental intrusion into matters so fundamentally affecting a person as the decision whether to bear or beget a child."93

A year later, however, the Court was more willing than before, though not without hesitation, ${ }^{94}$ to place the right of privacy in the fourteenth amendment's substantive guarantee of liberty. The Court found in Roe v. Wade ${ }^{95}$ that the right of privacy was "broad enough to encompass a woman's decision whether or not to terminate her pregnancy" in certain circumstances, "whether [that right] be founded in the Fourteenth Amendment's concept of personal liberty and restrictions upon state action, as we feel it is, or, as the District Court determined, in the Ninth Amendment's reservation of rights to the people . . . ."96 Justice Stewart, who dissented in Griswold but concurred in Roe, bluntly summarized the trend:

[I]t was clear to me then, and it is equally clear to me now, that the Griswold decision can be rationally understood only as a holding that the Connecticut statute substantively invaded the "liberty" that is protected by the Due Process Clause of the Fourteenth Amendment. As so understood, Griswold stands as one in a long line of ... cases decided under the doctrine of substantive due process . . . . ${ }^{97}$

Privacy might never have become a constitutional right independent of the right to liberty were it not for the Court's

the right [to privacy] has some extension to activities relating to marriage, Loving v. Virginia, 388 U.S. 1, 12 (1967); procreation, Skinner v. Oklahoma 316 U.S. 535, 541-542 (1942); contraception, Eisenstadt v. Baird, 405 U.S., at 453-454; ... family relationships, Prince v. Massachusetts, 321 U.S. 158, 166 (1944); and child rearing and education, Pierce v. Society of Sisters, 268 U.S. 510, 535 (1925) .... .

410 U.S. at $152-53$.

The lengthy citation to prior holdings under the first, fourth, and fifth amendments demonstrates how loath the Court was to appear to be substituting its own social judgment for that of state legislatures under the rubric of substantive due process.

${ }^{93}$ Eisenstadt v. Baird, 405 U.S. 438, 453 (1972).

${ }^{94}$ See note 92 supra.

95410 U.S. 113 (1973).

${ }^{96} I d$. at 153 (emphasis supplied).

${ }^{97} I d$. at 167-68 (Stewart, J., concurring) (footnote omitted). 
understanding of the early twentieth century loss of confidence in the judiciary as the institution primarily charged with translating changed social perceptions into constitutional law. The perception that the conditions of twentieth century life threatened privacy values still would have been the catalyst for constitutional protection of those values, but the right of privacy might well have been subsumed earlier, unhesitantly, and explicitly, in the broader guarantee of "liberty." Liberty of contract emerged because the text of the Constitution provided an explicit recognition of the right to "liberty" and ingenious jurists and judges were able to include "contract" in that liberty; it disappeared because freedom of contract eventually was perceived to be a false liberty, given the conditions of American life. Privacy emerged in its present form (or lack thereof) because the constitutional text does not explicitly protect it, because its protection was widely perceived to be vital, and because the unpopularity of the judicial constitutionalization of liberty of contract precluded the arguably more straightforward approach of interpreting "liberty" to include "privacy."

Privacy is as much a "doctrine" as liberty of contract; it protects currently significant values, here the autonomy of one's person and one's interest in being secluded. It may come to resemble liberty of contract in terms of its acceptance by judges as inalienable and sacred. It may also fall into disrepute. Numerous other constitutional doctrines, from the judicial "rule of reason" articulated in the late nineteenth century rate cases ${ }^{98}$ to "overbreadth" in the first amendment area today, ${ }^{99}$ while perhaps not as pervasive in their impact, are amenable to similar analysis.

\section{B. The Changing Interplay of Constitutional and Nonconstitutional Law}

One might wonder why the Supreme Court attempted to constitutionalize privacy at all, given its omission from the text of the Constitution and given twentieth century skepticism about

${ }^{98}$ See, e.g., Chicago, M. \& St. P. Ry. v. Minnesota, 134 U.S. 418 (1890); Smyth v. Ames, 169 U.S. 466 (1898).

${ }^{99}$ See, e.g., Shelton v. Tucker, 364 U.S. 479 (1960); United States v. Robel, 389 U.S. 258 (1967); Zwickler v. Koota, 389 U.S. 241 (1967); Coates v. Cincinnati, 402 U.S. 611 (1971).

Overbreadth may already have "peaked" in its primacy as a doctrine, see Broadrick v. Oklahoma, 413 U.S. 601 (1973). 
"substantive" judging. Some judges, including Justice Frankfurter, themselves espoused a limited view of the judiciary's constitutionalizing powers and opposed the Court's involvement in privacy cases. ${ }^{100}$ The Court's decision to reach the privacy issue in Griswold, after declining to pass on the constitutionality of the Connecticut statute three years earlier in Poe $v$. Ullman, ${ }^{101}$ evidenced its renewed confidence in the ability of constitutional law to solve social problems. This confidence paralleled the expansion of constitutional law in the 1950's and '60's into areas that had long been regarded as nonconstitutional territory. ${ }^{102}$ The developments of the 1950's and '60's illustrate that just as nonconstitutional and constitutional law have interacted throughout American history, they have also competed, their perceived jurisdictions expanding and contracting. Although the judiciary has attempted, as part of its constitutionalizing function, to identify the jurisdictional boundaries of nonconstitutional and constitutional law, it has not dictated those boundaries. The boundaries have been dictated implicitly by prevailing conceptions of the judiciary's proper role as a constitutionalizing agent. Those conceptions have been influenced not only by the presence of a written Constitution, the changing social and economic context of American history, and the current public stature of the courts, but also by the complexities of a federal system of government.

Each of the above variables came into play in the "great cases" decided by the Marshall Court. Gibbons v. Ogden ${ }^{103}$ is an example. That case was decided late in Marshall's tenure; the pattern of "final" interpretation of the Constitution by the Supreme Court had already been established. Marbury $v$. Madison, ${ }^{104}$ Fletcher v. Peck, ${ }^{105}$ Trustees of Dartmouth College v. Woodward, ${ }^{106}$ McCulloch v. Maryland, ${ }^{107}$ and Cohens v. Virginia,${ }^{108}$ taken together, evidenced the Court's involvement in and resolu-

${ }^{100}$ In announcing the judgment of the Court in Poe v. Ullman, 367 U.S. 497 (1961), Justice Frankfurter seized upon the relative absence of prosecutions under the Connecticut birth control statute as a means to avoid reaching the merits of the case. Id. at 507-09.

${ }^{101} I d$.

${ }^{102}$ See notes $146-49$ infra \& accompanying text.

10322 U.S. (9 Wheat.) 1, 212-21 (1824).

${ }^{104} 5$ U.S. (1 Cranch) 137 (1803).

10510 U.S. (6 Cranch) 87 (1810).

10617 U.S. (4 Wheat.) $518(1819)$.

10717 U.S. (4 Wheat.) 316 (1819).

10819 U.S. (6 Wheat.) 264 (1821). 
tion of highly charged social issues and implicitly communicated a national judiciary's concern with ostensibly local questions. Gibbons was in the same vein. It was first an exercise in judicial interpretation of the constitutional principle of interstate commerce; second, an inquiry into the monopoly status of statesupported steamboat companies; third, a test of the Court's ability to function in a "common law" capacity, in this instance by assessing and responding to emerging entrepreneurial values; and fourth, an inquiry into the prospective scope of the federal judiciary's supervision, through its mandate to interpret the Constitution, of state economic regulation.

Potentially competing in Gibbons were two roles for the judiciary in America: that of common law synthesizer and that of constitutional interpreter. The common law in America had become highly localized by the time of the Constitution: $\mathrm{Pa}$ rochial points of view had created diverse common law rules and doctrines. The growing influence of the judiciary in the states in the late eighteenth and early nineteenth centuries was in part a product of its ability to modify existing common law doctrines to reflect changing parochial attitudes. Gibbons raised the question whether a federal judiciary, in the person of the Supreme Court, could perform its role as interpreter of constitutional principles in a manner consistent with the now entrenched role of common law judges. Gibbons, then, presented a delicate problem of constitutionalization: Could the Court maintain the integrity of constitutional principles without offending the emergent American version of common law adjudication? Could it secure a result acceptable to the many factions of the populace while preserving its power to scrutinize local laws in the name of the Constitution?

The great success of Marshall's opinion in Gibbons, described as "one of the most powerful efforts of the human mind that has ever been displayed from the bench of any court"109 and the "one and only ...'popular" "110 decision of Marshall's career, was its ability to integrate "common" and "constitutional" lawmaking. Marshall refined ancient English doctrines about the use of navigable waters to conform to the interstate character of American rivers; he lent support to the value of economic com-

${ }^{109}$ New York Evening Post, Mar. 5, 1824, quoted in C. Warren, History of THE AMERICAN BAR 395 (1911).

110 A. Beveridge, 4 The Life of John Marshall 445 (4 vols. 1919). 
petition as opposed to protectionist values; he provided a powerful stimulus for the expansion of trade and commerce into the interior of the American continent. These positions were consistent with influential American common law adjudication. Marshall expanded the meaning of the Constitution's commerce clause, embracing navigation in its coverage, at the same time as he expanded the potential range of federal regulatory power (although that power would lie dormant for many years hence), and thereby increased the potential power of the federal judiciary to decide commercial questions affecting local interests. Gibbons was vintage American common law adjudication and activist constitutional interpretation in the same case. It achieved a harmony between the component parts of the early nineteenth century system of American jurisprudence.

But jurisprudential integration of the Gibbons variety was the rare exception throughout the nineteenth century. First, the "common law" function of the judiciary became complicated by the increased presence of state statutes promoting new policies. Second, the function of the judiciary in constitutional interpretation became complicated by the collapse of "natural law" as an extra-constitutional source to which judges could appeal. Third, social issues appeared, most notably slavery, that had ominous implications for prospective harmony between the federal government and the states. Fourth, population growth and territorial expansion in the nineteenth century interacted with the legacy of local consciousness from colonial times to produce a thoroughgoing regionalization of nineteenth century American society. All these factors combined to create a potential for competition between constitutional and nonconstitutional law. In the Dred Scott case ${ }^{111}$ that competition placed the Supreme Court in an insoluble dilemma.

In the uncertain atmosphere of rapid economic change in early nineteenth century America, state legislatures and prospective entrepreneurs sought ways of promoting growth without undermining economic security. Various versions of state/private economic partnerships developed, with varying degrees of state regulation of entrepreneurial activity. ${ }^{112}$ In general, the thrust of this development was a greater proliferation of state statutes and

111 Dred Scott v. Sandford, 60 U.S. (19 How.) 393 (1857); see text accompanying notes 118-20 infra.

${ }^{112}$ See sources cited note 66 supra. 
a subtle alteration of the "common law" function of the judiciary. Leading common law judges, such as Lemuel Shaw of Massachusetts, sensed their vulnerability as "lawmakers" in the face of legislative activity, yet were reluctant to surrender their lawmaking powers altogether. ${ }^{113}$ Their responses, which varied in degree and in content from state to state, can be described generally as professed deference to legislative authority and retention of a "supplementary" interpretive role to aid state legislatures in implementing their desired policies. The judges' approach has been described as "instrumentalist": ${ }^{114}$ It sought to fuse statutory and common law in the pursuit of desired social policies.

The "common law" component of American jurisprudence was thus significantly altered by the middle of the nineteenth century, with serious implications for the continued primacy of judicial lawmaking in nonconstitutional areas. Indeed, some who feared judicial power sought to restrict severely the freedom of common law judges to make law by implementing a general codification of American laws which everyone could understand and which would require little judicial interpretation. ${ }^{115}$ At the same time juristic thought, evinced an increasing skepticism about the independent viability of natural law. Appeals beyond the Constitution to "general principles which are common to our free institutions," 116 such as Justice William Johnson had made in Fletcher v. Peck, came into disfavor. ${ }^{117}$ The consequence of this last development was a recognition of the Constitution as the exclusive source of natural rights principles, and a tacit reluctance to permit judicial use of "higher law" sources other than the Constitution's text. This exerted strong pressure on the Constitution to incorporate prevailing notions of reason and justice, and attendant pressures on the judiciary to effectuate that incorporation. Complicating matters even more was the demise of consensual values which accompanied the collapse of natural law as an independent entity during the nineteenth century re-

${ }^{113}$ A comprehensive treatment of Chief Justice Shaw's decisions is found in $L$. Levy, The Law of the Commonwealth and Chief Justice Shaw (1957).

114 Horwitz, supra note 51.

115 See R. Cover, supra note 63, at 140-44; P. Miller, The Life of the Mind in AMERICA 49-109, 239-65 (1966).

${ }^{116}$ Fletcher v. Peck, 10 U.S. (6 Cranch) 87, 143 (Johnson, J., concurring).

117 For an account of the disappearance of "natural law" as an entity independent of the Constitution, see R. Cover, supra note 63, at 33-193. 
gionalization of American life. ${ }^{118}$

The Dred Scott case came to a Supreme Court caught up in these swirling pressures. Under Chief Justice Taney the Court had shown signs of developing an "instrumentalist" posture, promoting regionalism and industrial expansion by deferring to the judgment of state legislatures, despite the legacy of broad federal primacy bequeathed it by former Chief Justice Marshall. ${ }^{119}$ Constitutional adjudication by the Taney Court became an exercise in political compromise between clashing regional interests. Could the Court maintain its position of primacy in the area of slavery by endorsing certain states' solutions to the slavery problem, thereby constitutionalizing the common law property doctrines as they had been applied to slaves? Or should the Court, as the final interpreter of the supreme source of natural rights in America, confront squarely the conflict between slavery doctrines and natural rights principles, resolving that conflict one way or the other as a matter of constitutional law?

The juristic dilemma of Dred Scott was thus a dilemma brought about by conflict between two types of law and two judicial roles. In seeking to address this dilemma the Court received little guidance from an appeal to consensual values or to fundamental principles. No national consensus existed on how to "solve" the problem of slavery; the Constitutional text was explicitly ambiguous about the place of the institution in a republic based on natural rights principles, especially equality; and appeals to natural law itself were no longer permissible. Hence the Taney Court could only guess whether a full-blown constitutionalization of the legal doctrines governing slavery, which Dred Scott accomplished by freeing those doctrines from regional contexts and permitting their extension into new territories, would resolve the slavery question conclusively. The Court, of course, guessed wrong. The constitutional principle of natural rights and the common law doctrines governing slavery were in irreconcilable conflict and could not be integrated.

The "wrong guess" in Dred Scott lowered the stature of the Court drastically and threatened the continued primacy of

${ }^{118}$ See text accompanying note 49 supra.

119 See, e.g., Cooley v. Board of Wardens, 53 U.S. (12 How.) 299 (1852); License Cases, 46 U.S. (5 How.) 504 (1847); City of New York v. Miln, 36 U.S. (11 Pet.) 102 (1837); Charles River Bridge v. Warren Bridge Co., 36 U.S. 341, 11 Pet. 420 (1837); The TANey Period, supra note 63, at 360-65, 370-77. 
judges as lawmakers. But in the forty-odd years after 1870 the judiciary was able to reassert and even expand its lawmaking power, again by successfully integrating constitutional and nonconstitutional law. Several factors contributed to this judicial renaissance. First, the federal judiciary's interpretive powers were potentially expanded by the adoption of the Reconstruction Amendments, ${ }^{120}$ which placed constitutional limitations on the states through an impressively broad and general textual apparatus highlighted by such terms as "liberty," "due process," and "equal protection." Second, institutional competitors of the judiciary suffered a decline in public esteem. The public viewed Congress and the state legislatures as partisan and corrupt, the executive branch as inconsequential. ${ }^{121}$ Third, a new conception of the relationship between the individual and the government emerged, emphasizing the ability of Americans, especially those in the business community, to master their own destinies and to organize their own affairs. Governmental control of the economy became unfashionable: The state/private partnerships of the antebellum period survived the Civil War but declined thereafter; hostility developed toward state statutes regulating industrial enterprise, and, in general, regulation by the states declined even in areas in which regulation could have been constitutional. ${ }^{122}$ Finally, the excitement generated by rapid industrialization, coupled with the dissipation of sectional animosities, superficially united Americans behind an ethic of material progress which became a new "first principle" cognizable by constitutional law. ${ }^{123}$ The interaction of these factors made possible a series of judicial accommodations of constitutional provisions to new nonconstitutional developments.

One can identify several such accommodations: liberty of contract, based upon the stringent rules of the common law of contracts; the expansion of the term "persons" in the due process clause of the fourteenth amendment to protect the corporate form of enterprise, ${ }^{124}$ itself a "common law" creation; a

${ }^{120}$ U.S. Const. amends. XIII, XIV, XV.

121 See generally L. White, The Republican ERA 1869-1901 (1958).

122 See J. Hurst, supra note 66; E. KrRkLand, Dream and Thought in the Business Community, 1860-1900 (1956); A. Paul, Conservative Crisis and the Rule OF LAW (1960).

${ }^{123}$ See P. Buck, The Road to Reunion 1865-1900 (1937); R. Gabriel, The Course of American Democratic Thought 281-99 (2d ed. 1956).

${ }^{124}$ Santa Clara County v. Southern Pac. R.R., 118 U.S. 394, 396 (1886); see also text accompanying note 67 supra. 
construction of the fourteenth amendment's equal protection clause to permit "equal" racially segregated facilities, ${ }^{125}$ an innovation of state legislatures in the South. Unlike the Gibbons Court, the late nineteenth century Court did not innovate in the area of constitutional interpretation but simply incorporated nonconstitutional innovations by reference. Liberty of contract was a creation of jurists and state courts; the inclusion of corporations within the meaning of "persons" was conceived by railroad lawyers seeking to prevent legislative encroachment on their clients' holdings; ${ }^{126}$ the doctrine of "separate but equal" was developed by white legislators in the South. ${ }^{127}$ Only occasionally was the Court required to innovate on its own, as in the Knight case, ${ }^{128}$ in which the Court sought to accommodate the Sherman $\mathrm{Act}^{129}$ to the Constitution for the purpose of protecting yet another nonconstitutional innovation, the conglomerate enterprise or "trust." In Knight the Court had to come up with a novel reading of the commerce power to exclude manufacturing enterprises.

By and large then, the Court's stance was that of toleration of nonconstitutional innovations rather than activism as such. But toleration became a form of judicial activism. The expanded Constitution served, in the late nineteenth and early twentieth centuries, both as a bulwark against legislative encroachments on private enterprise and as a blueprint for continued legislative efforts to achieve racial segregation. The judiciary as a constitutionalizing agent functioned as a "negative power, the power of resistance,"130 against attempts by government or private groups to curtail activities based on values and attitudes the Court perceived as dominant.

As late as World War I important state courts, such as the Court of Appeals of New York, persisted in this variety of

${ }^{125}$ E.g., Plessy v. Ferguson, 163 U.S. 537 (189̄6).

${ }^{126}$ See B. Twiss, LAwYers AND THE Constitution 60-61, 94 (1942).

${ }^{127}$ The Court's deference to legislatures in the segregation cases should not be considered abdication of its constitutionalizing function. The deference was professed rather than actual: In Plessy, for example, the Court announced a doctrine that effectuated what it perceived to be the prevailing social attitude. Actual deference to legislative judgment, exemplified by the "rationality" standard later applied to legislative judgments, see text accompanying notes 137 \& 138 infra, represents the Court's decision to refrain from conceptualizing social attitudes it views as currently prevailing.

${ }^{128}$ United States v. E.C. Knight Co., 156 U.S. 1 (1895).

12915 U.S.C. $\$ \S 1-7$ (1970).

${ }^{130}$ Letter from Justice Stephen Field to the Chief Justice and the Associate Justices of the Supreme Court of the United States, Oct. 12, 1897, in 168 U.S. 713, 717. 
resistance; ${ }^{131}$ and a majority of Supreme Court justices consistently thought of the Constitution as a source of protection for particularistic values through the 1920's. ${ }^{132}$ By 1940, however, a much more limited jurisdictional definition of "constitutional law" had become accepted, nonconstitutional law innovations had proliferated in changed forms, and both the "common law" and "constitutional" powers of the judiciary had been curtailed sharply. Again, a mix of social and intellectual factors contributed to this sudden change. Economic crisis prompted a dramatic expansion of the regulatory powers of the federal government, particularly through administrative agencies. That crisis was one facet of a growing awareness of the costs of mature industrialism, including discrepancies in income, status, and health which mocked America's alleged commitment to egalitarianism. The judiciary's open resistance to experimental state and federal legislation that tried to alleviate some of these costs rebounded to its political disadvantage. Most importantly, the posture of resistance initiated by the late nineteenth century judiciary became characterized, as it continued into the twentieth century, as a selective, partisan reading of the Constitution, a substitution of the will of the judge for the will of the law.

That charge revived an old and painful theme. Despite the close identification of common law adjudication with the promotion of dominant social attitudes in colonial and revolutionary America, despite the thoroughgoing activism of Chief Justice Marshall and the policymaking posture of mid-nineteenth century judges, and despite the particularistic glosses on the Constitution written by judges at the close of the nineteenth century, judges were not prepared to acknowledge themselves as lawmakers. Nor, in the main, were they so perceived. When Justice David Brewer announced in 1893 that "the courts make no laws," "establish no policy," "never enter into the domain of public action," and "do not govern," 133 his intended meaning was not ironic. His attitude was rather a posture thought necessary to maintain the independence of a judiciary that was by and large not democratically selected. To suggest openly that judges

${ }^{131}$ See, e.g., Ives v. South Buffalo Ry. Co., 201 N.Y. 271, 94 N.E. 431 (1911), invalidating a New York workmen's compensation statute.

${ }^{132} 1$ W. Swindler, Court and Constitution in the Twentieth Century 223-303 (2 vols. 1969).

${ }^{133}$ Proceedings of the New York Bar Association 46 (1893). 
"made law" was to raise the spectre of unchecked judicial bias and to revive the eighteenth century fears of judicial tyranny.

Yet in the 1920's and '30's the effect of individual bias in judicial decisionmaking was fully addressed. In a time of rapidly changing perceptions about governmental regulation of economic and social affairs, it seemed that many justices of the Supreme Court and judges on lower courts subscribed to nineteenth century social theories and equated them with "law." Their attitudes, once exposed, cast serious doubt on the premises of impartiality and humility from which the American judiciary supposedly started..$^{134}$ The long-term result of this crisis of legitimacy for the judiciary was the triumph of a "realistic" understanding of judicial lawmaking and the advent of jurisprudential theories oriented toward curbing judicial power. ${ }^{135}$

An important side effect of this altered view of judging was a redefinition of the interaction between nonconstitutional and constitutional law in America. The association in the public mind of certain constitutional doctrines with the social predilections of judges paved the way for a contracted view of the Constitution's jurisdiction and a corresponding expansion of lawmaking by public institutions (legislatures and especially administrative agencies) and private groups. ${ }^{136}$ No one case represented the trend, but a general pattern emerged. Private groups, legislatures, and agencies regulated the activities of Americans through multifaceted rules, contracts, union-management negotiations, and statutes. The ambits of traditional common law judging and constitutional adjudication were redefined to insure greater judicial deference to the "reasonable" decisions of private and especially public lawmakers. ${ }^{137}$ Only in egregious cases, such as the appropriation of property without just compensation ${ }^{138}$ or the failure to provide aggrieved parties with minimal procedural safeguards, ${ }^{139}$ did the judiciary scrutinize the acts of other law-

${ }^{134}$ For a discussion of the embattled status of courts in the 1930's, see R. JACKson, The Struggle for Judicial Supremacy (1941).

${ }^{135}$ The relationship of realism to the Court-packing cases of the 1930's is discussed in White, The Evolution of Reasoned Elaboration: Jurisprudential Criticism and Social Change, 59 VA. L. REv. 279, 281-82 (1973). See generally R. JACKson, supra note 134, at 124-96. 136 "Lawmaking" by private groups means the ordering of social and economic relationships by nongovernmental institutions.

${ }^{137}$ See, e.g., Nebbia v. New York, 291 U.S. 502, 525 (1934).

${ }^{138}$ See, e.g., United States v. Causby, 328 U.S. 256 (1946).

${ }^{139}$ C.f. Bowles v. Willingham, 321 U.S. 503 (1944). 
making institutions. Application of the due process clause was limited to procedural matters; the equal protection clause was understood to invalidate only "arbitrary" (as opposed to "reasonable") classifications. ${ }^{140}$ Self-conscious judges assumed postures consistent with the trends. Felix Frankfurter stressed the selfimposed limitations of his office; ${ }^{\mathbf{1 4 1}}$ Learned Hand wondered whether the role of the judiciary in constitutional adjudication was anything more than communicating the "moral adjurations" of the Bill of Rights. ${ }^{142}$

By the 1950's the above pattern had spawned a novel set of . insights into law in America, which emphasized the process by which legal institutions interact rather than the content of law itself. ${ }^{143}$ If postwar American lawmakers-"private orderers," agencies, legislatures, and courts-understood their respective functions and operated within their limits of competence, the "legal process" would produce efficient and just laws. ${ }^{144}$

At first this conception of law and legal institutions appeared to depart from the traditions of American jurisprudence in minimizing the roles of the Constitution and the judiciary. The primary lawmaking agents appeared to be private groups and the new public lawmakers. The judiciary seemed destined to revert to a passive stance, losing most of its "common law" powers to legislatures and administrative agencies and constitutionalizing areas only when "neutral principles" of constitutional law justified the intrusion. ${ }^{145}$ In a different context these

${ }^{140}$ See, e.g., Railway Express Agency, Inc. v. New York, 336 U.S. 106 (1949).

141 See F. Frankfurter, Of Law and Men 16-30, 53-56 (1956).

${ }^{142}$ See L. HANd, The Bill of Rights 1-30, 56-77 (1958).

${ }^{143}$ For a recent discussion of substantive values embodied in law, see L. Fuller, The Morality OF LAW (1964).

144 The terms "private ordering" and "legal process" were created and introduced into the law school curriculum by $H$. Hart \& A. Sacks, The Legal. Process (tent. ed. 1958).

${ }_{145}$ Cf. Wechsler, Toward Neutral Principles of Constitutional Law, 73 Harv. L. Rev. 1, $14-20$ (1959).

Let me repeat what I have thus far tried to say. The courts have both the title and the duty when a case is properly before them to review the actions of the other branches in the light of constitutional provisions, even though the action involves value choices, as invariably action does. In doing so, however, they are bound to function otherwise than as a naked power organ; they participate as courts of law. This calls for facing how determinations of this kind can be asserted to have any legal quality. The answer, I suggest, inheres primarily in that they are-or are obliged to be-entirely principled. A principled decision, in the sense $I$ have in mind, is one that rests on reasons with respect to all the issues in the case, reasons that in their generality and their neutrality transcend any immediate result that is involved. When no sufficient 
hypothetical roles for judges and the Constitution might have been realized. Events of the 1950's and '60's, however, propelled the federal judiciary into a far more active lawmaking stance, resulting in a marked expansion of the ambit of constitutional law and a renewed judicial interest in ensuring that nonconstitutional innovations of the twentieth century conformed to newly perceived constitutional mandates.

The early twentieth century reorientation of juristic emphasis had minimized the substantive content of individual rights and the power of the judiciary to preserve rights against the state. Amid enhanced governmental planning, pressures for national solidarity, and the unprecedented economic crisis of the 1930's and '40's, a deemphasis of individual autonomy seemed appropriate. After the Second World War, however, revelation of the atrocities of Nazi "planning" fostered an environment conducive to more searching scrutiny of discrimination and inequality in American life. But the process of governance in America continued apace, the nonconstitutional lawmakers of the 1930's maintaining their presence and viability. Their laws represented a complex adjustment of conflicting interests by administrators and legislatures, or negotiated compromises among interested groups. They did not define their task, however, as the vindication of individual rights and liberties; when pressure for that vindication came, especially in the area of civil rights, they appeared hesitant or unwilling to respond. A void was created for the swift affirmation of principles of liberty and equality, given a new meaning by the Second World War and exemplified by a heightened sense of the constitutional rights of individuals. Into that void stepped the Warren Court.

The boundaries between constitutional and nonconstitutional law were blurred once again as the Warren Court found that state or federal legislation segregating public schools, ${ }^{146}$ apportioning voter representation, ${ }^{147}$ fashioning rules of criminal

reasons of this kind can be assigned for overturning value choices of the other branches of the Government or of a state, those choices must, of course, survive. Otherwise, as Holmes said in his first opinion for the Court, "a constitution, instead of embodying only relatively fundamental rules of right, as generally understood by all English-speaking communities, would become the partisan of a particular set of ethical or economical opinions ...."

Id. I9 (footnote omitted).

${ }^{146}$ Brown v. Board of Educ., 347 U.S. 483 (1954).

${ }^{147}$ Baker v. Carr, 369 U.S. 186 (1962). 
procedure, ${ }^{148}$ compelling prayers in public schools, ${ }^{149}$ or suppressing "subversive" speech ${ }^{150}$ violated constitutional principles. Over a period of about fifteen years, beginning in the mid1950's, the Warren Court continually expanded the meaning of constitutional rights and held other lawmaking institutions accountable to the dictates of the Constitution. As lower courts followed the trend, the judiciary revived one of its major roles. The constitutionalization process took on a new but not unprecedented form. Unlike the "passively activist" courts of the late nineteenth century, ${ }^{151}$ the mid-twentieth century judiciary constitutionalized nonconstitutional law by requiring existing governmental institutions to confer procedural safeguards on persons affected by their decisions or to use "fair" or "equal" standards in their decisionmaking. ${ }^{152}$ The late nineteenth century judiciary, in contrast, had sought to prevent government from regulating the affairs of private persons. Whereas in the late nineteenth century the judiciary permitted nonconstitutional doctrines to infiltrate into the corpus of constitutional law, in the mid-twentieth century the judiciary imposed constitutional principles upon the already expanded domain of nonconstitutional law in modern America. The courts constitutionalized current values and attitudes before they had been identified or adopted by other lawmaking institutions. ${ }^{153}$

\section{The Juristic Perspectives of American Legal Scholarship: Changing Conceptions of Legal History in America}

Although the shifting interplay of constitutional and nonconstitutional law and the rise and fall of constitutional doctrines are dominant themes in the history of American jurisprudence, they are made even more discernible by the phenomenon of periodization in American history. Interactions between events and ideas have produced basic shifts in cultural values and attitudes which lend themselves, with the perspective of hindsight, to rough characterizations and demarcations. Historical periodi-

${ }^{148}$ E.g., Gideon v. Wainwright, 372 U.S. 335 (1963); Miranda v. Arizona, 384 U.S. 436 (1966).

149 Engel v. Vitale, 370 U.S. 421 (1962).

${ }^{150}$ E.g., Yates v. United States, 354 U.S. 298 (1957).

151 See generally text accompanying notes 121-30 supra.

152 See, e.g., Levy v. Louisiana, 391 U.S. 68 (1968); Miranda v. Arizona, 384 U.S.

436 (1966); Griffin v. Illinois, 351 U.S. 12 (1956).

${ }^{153}$ See also text accompanying notes $103-13$ supra. 
zation is a present-oriented phenomenon: The value orientation of a past "era" or "generation" is implicitly compared or contrasted with the present value orientation of the historian. The history of blacks in America became revitalized with the advent of the civil rights movement in the 1960's; the same is true of the history of women in the 1970's. Not only do the heroes and villains of history change with time; ${ }^{154}$ so do the subjects of historical inquiry and the methodologies by which those subjects are approached. Historical writing by legal scholars is no exception. However faithfully lawyer historians try to reproduce the past, their sense of historical progression and demarcation and their modes of observation and analysis are products of the present.

The purpose of this section is to suggest that the "juristic mix" of various periods in American history-the complex interaction of ideas and events that produces a discernible social and intellectual perspective-affects conceptions of legal history just as it affects conceptions of the Constitution, nonconstitutional law, and judging. Moreover, the "legal history" written by lawyers at various times complements other juristic positions advanced at the times. The scholarly contributions of influential lawyer historians from four periods in American history will be used as illustrations.

The most influential legal historians of the late eighteenth and early nineteenth centuries, when American jurisprudence took on its distinctive character, were James Kent and Joseph Story. ${ }^{155}$ As noted, between 1790 and 1840 common law and constitutional law proliferated but did not often compete: Constitutionalization could sometimes be effectuated without strain, and judges functioned creatively both as constitutional interpreters and as common law adjudicators. ${ }^{156}$ Few serious conflicts between parochial common law rules and constitutional principles developed; when they did, as in the case of slavery, provisional resolutions took place. Law and legal institutions were expanding; American jurisprudence was in a phase of growth. In this atmosphere the scholarship of Kent and Story, themselves judges as well as scholars, supplied an authoritative corpus

\footnotetext{
${ }^{154}$ For example, changing public attitudes toward Thomas Jefferson are discussed in M. Peterson, The Jefferson Image in the American Mind (1960).

${ }^{155}$ E.g., J. Kent, Commentaries on American Law (1826-1830); J. Story, Commentaries on Equity Jurisprudence (1836); J. Story, Commentaries on the ConSTITUTION OF THE United States (1838).

${ }^{156}$ See text accompanying notes 103-13 supra.
} 
of "law"-rules, principles, axioms, and doctrines, of "common," "constitutional," and "natural" origin-that could guide the affairs of a new nation. Story's and Kent's methodological approach to their subject matter was synthetic. They combed diverse sources and extracted seemingly authoritative rules and doctrines, analogous to the "great principles" on which Marshall rested his decisions. Their scholarship was comprehensive, encompassing all existing fields of nonconstitutional and constitutional law; their methodology was designed to filter the contributions of the ancients through the special perspective of the new American republic. Legal history for them was part of the grand design of American jurisprudence. They reinforced the wisdom of the past by restating it, discarding whatever they perceived as inapposite or inimical to the American experience. ${ }^{157}$

The grand integrative syntheses of ancient and contemporary materials that characterized Kent's and Story's legal history complemented the simultaneous, and generally noncompetitive, expansion of common and constitutional law in the early nineteenth century. Both developments were linked to an interest among American jurists in creating an indigenous jurisprudence. Just as the common law was becoming "Americanized" and the principles of a written Constitution were interpreted as contributing to the uniqueness of the American republic, so the great treatises of Kent and Story produced a nationalistic version of legal history, in which selected insights of ancient jurists were shown to be applicable to the American experience.

The next major American legal historian of the nineteenth century was Oliver Wendell Holmes, Jr. ${ }^{158}$ Holmes' The Common Law, published in 1881 , was in one sense a protest against certain intellectual assumptions of some of his contemporaries, ${ }^{159}$ but was in another sense representative of late nineteenth century juristic perspectives. Holmes believed that the dominant legal

${ }^{157}$ See generally G. DUNNE, supra note 62; L. FRIEDMAN, supra note 55, at 288-92 (Kent); J. Horton, supra note 62; J. McClellan, Joseph Story and the American Constitution 61-193 (1971).

${ }^{158}$ Important theoreticians, including Thomas M. Cooley, Sidney George Fisher, Francis Lieber, Joel Parker, John Norton Pomeroy, and Robert Rantoul, surfaced among legal scholars between 1840 and 1870, but their scholarship was not historically oriented. P. Paludan, A Covenant with Death (1975), analyzes the work of Cooley, Fisher, Lieber, Parker, and Pomeroy.

159 "The life of the law has not been logic: it has been experience." O.W. Holmes,

The Common Law 1 (1881). 
theories of his time were to be derived from nonconstitutional sources. The "principle" that "loss from accident must lie where it falls," 160 for example, emerged from the experience of the marketplace. By emphasizing common law subjects and by attempting to develop a theory through which majoritarian impulses could operate, Holmes' analysis was analogous to the approach of late nineteenth century judges who sought (perhaps unconsciously) to expand the Constitution to encompass widely accepted nonconstitutional doctrines.

Holmes' approach to legal history in The Common Law was representative of his age in a more fundamental sense. Whereas Kent's and Story's methodology had been intended to amass a useful storehouse of relevant information from the past, Holmes' method in The Common Law was intended, as he later stated, to free his generation from the past. ${ }^{161}$ The function of history in The Common Law was to show the futility of erecting legal rules based on logic: Rules never survived their utility in a particular context. Because rules could not be immutable, contemporary Americans were free to derive their own, based on "the felt necessities"162 of the times.

Story and Kent used legal history as a vehicle for a grand synthesis; Holmes used data from the past as raw material for a theory. Story and Kent had been selective in their methodology, but not in their subject matter. They presented their audience of neophyte jurists with a wealth of information that revealed, almost coincidentally, the primacy of certain "principles" such as the inviolability of property rights.

Holmes presented his readers with what he considered an appropriately deterministic explanation of the law's growth over time. ${ }^{163}$ Holmes argued that law responds to unconscious and

${ }^{160}$ Id. 94 .

${ }^{161}$ O.W. Holmes, Law in Science and Science in Law, in Collected Legal Papers $210,225(1920)$.

162 O.W. Holmes, supra note 160 , at 1.

${ }^{163}$ See G. Gilmore, The Death of Contract 14-31 (1974) for a discussion of Holmes' analysis of common law principles:

It seems perfectly clear that Holmes was, quite consciously, proposing revolutionary doctrine and was not in the least interested in stating or restating the common law as it was. He was, at the time he wrote the lectures which make up The Common Law, as learned in the history of the law-including the law of contracts-as any lawyer in the English-speaking world. Yet his analysis of the true meaning of "consideration" comes forth almost naked of citation of authority or precedent. He starts with an off-hand reference to what is commonly "said" and commonly "thought." However, what is clear to Holmes "has 
changing majoritarian impulses, so that it can never be static. To understand the course of legal history one only has to recognize and accept the primacy of majority will. Then one could be satisfied, in a democracy, with the knowledge that "the crowd" was "getting all it wanted" and reserve the pleasure of criticizing the crowd for the folly of its judgments. ${ }^{164}$

Holmes' interest in history as a source of a theory was congenial to the thinking of late nineteenth century jurists. The late nineteenth century was an age of conceptualism, in which judges and scholars sought clear and practicable governing rules or doctrines in both constitutional and nonconstitutional law. But the relativism of Holmes' end product was less acceptable to his peers. (The Common Law made its greatest impact in the twentieth century, when its relativism came to be viewed as philosophically sound and its deference to majoritarian lawmaking seemed to make good sense.) ${ }^{\mathbf{1 6 5}}$ Holmes' theory was too unpredictable and passive for late nineteenth century jurists. They sought the affirmative development of workable doctrines and rules. They prized certainty in the law. They wanted law to be a science with governing axioms and concepts. They were eager to perform the exercises in syllogistic logic that Holmes decried. Ultimately, they believed that truth was an ascertainable entity, whereas Holmes found "truth" in the "majority vote of that nation that could lick all others." 166

For all the originality of Holmes' perspective in The Common Law, and for all of its affinity to the leading edge of late nineteenth century jurisprudence, his approach was too unconventional to be influential in its own time. Holmes refused to reduce his relativistic theories to rigid concepts from which judges could deduce results. Roscoe Pound, who never achieved the insight or vision of Holmes, was for a time more influential. It was Pound rather than Holmes who provided the principal bridge between nineteenth century juristic conceptualism and the empirically oriented "realist" thinking of the early twentieth century.

not always been sufficiently borne in mind" by others. Whereupon, we are off to the races at a dizzying clip.

Id. 20-21 (footnotes omitted).

${ }^{164}$ See, e.g., 1 Holmes-Laski LetTers 207 (Howe ed. 1953).

${ }^{165}$ See generally White, The Rise and Fall of Justice Holmes, 39 U. CHI. L. REv. 51, 56-65 (1971).

${ }_{166}$ O.W. Holmes, Natural Law, in Collected Legal Papers 310 (1920). 
Pound made his initial impact on the legal profession as a critic of conceptualism, which he called "mechanical jurisprudence." ${ }^{67}$ Conceptualist thinking was a product of the same late nineteenth century juristic mix that generated the expansion of constitutional law to incorporate emerging nonconstitutional doctrines. ${ }^{168}$ The distinguishing features of conceptualism were controlling assertions-whether axioms, maxims, glosses, or doctrines-which were announced to be true and then used as the basis for syllogistic reasoning to an end result. The doctrine of liberty of contract was one such assertion; it yielded the result, in one case, that a statute regulating the permissible number of working hours in the baking industry was unconstitutional. ${ }^{169}$ The distinction drawn between "manufacture" and "commerce" in the Knight case was another. ${ }^{170}$ Pound attacked conceptualist opinions as oblivious to changing social conditions and imprisoned in their own ritualistic logic, which he felt rested primarily on a priori postulates. ${ }^{171}$ But while calling for a "sociological jurisprudence" by which courts would broaden their inquiries and increase their social awareness, ${ }^{172}$ Pound continued to employ a conceptualist methodology in his historical scholarship.

Foremost among his use of conceptualist devices was his use of classification. Pound attempted to undermine the primacy of mechanical jurisprudence by showing that it was only one of several "schools" in the history of juristic thought. Nineteenth century American jurisprudence, he argued, had included a "creative" school, a "historical" school, and an "analytical" school; mechanical jurisprudence was simply the analytical school in its latter stages of decay. ${ }^{173}$ Pound did not define the characteristics of each of the "schools" clearly, but he made his point clearly enough: Because ideas moved in and out of vogue over time, no one idea could claim universality. The purpose of mechanical

${ }^{167}$ Pound, Mechanical Jurisprudence, 8 Colum. L. Rev. 605 (1908).

${ }^{168}$ See text accompanying notes 121-30 supra.

${ }^{169}$ Lochner v. New York, 198 U.S. 45 (1905).

170 United States v. E.C. Knight Co., 156 U.S. 1 (1895). The distinction allowed a corporation controlling over $90 \%$ of the nation's sugar production to avoid the strictures of the Sherman Act.

171 Pound, supra note 73 , at 457.

172 Pound, The Need of a Sociological Jurisprudence, 19 GREEN BAG 607 (1907).

${ }^{173}$ Pound summarized his earlier views on the history of juristic thought in $R$. Pound, The Formative Era of American Law 93-118 (1938). See also Pound, supra note 172 , at $608-10$. 
jurisprudence had been to create and to utilize "universals,"174 but that purpose was futile.

Or so Pound seemed to be saying in his reformist writings of the early twentieth century. As sociological jurisprudence became more orthodox in legal scholarship, however, and as Pound himself became part of the established academic order as Dean of Harvard Law School, the affinity of his thinking with conceptualism became apparent. Pound conceived of history not merely as a series of changing "felt necessities," but as a progression of refined truths. There was a "taught legal tradition"175 that remained constant in the face of change; stability and predictability in adjudication were values to be prized; natural law, in different embodiments, was a continuous thread of American jurisprudence. ${ }^{176}$ Pound eventually suggested that the "legal order" could be "partitioned" into compartments: In some, such as property and commercial transactions, the late nineteenth century desire for certainty should predominate; in others, such as administrative and constitutional law, "the flexibility required for the individual life"177 should be accommodated. The initial classification determined the subsequent treatment, just as the initial maxim had set forth the process of syllogistic reasoning in late nineteenth century judicial decisions.

Hence Pound stood firmly in the mode of nineteenth century conceptualist thinking; his link to subsequent juristic developments in the twentieth century came chiefly from his recognition that the context of law was broader than "scientific" conceptualism admitted, ${ }^{178}$ and consequently that a variety of institutions could perform lawmaking functions simultaneously. In his characterization of history as a source of permanent truths and in his conviction that a conceptualist methodology could extract these truths, however, Pound was far closer to the mechani-

${ }^{174} \mathrm{R}$. Pound, supra note 173 , at 110 .

175 Id. 82.

${ }^{176}$ Id. $110-16$.

${ }^{177} \mathrm{Id} .118$.

${ }^{178}$ Cf. C. Langdell, Selection of Cases on the Law of Contracts viii (2d ed. 1879) (Preface to the First Edition): "Law, considered as a science, consists of certain principles or doctrines. ... [T] [Te number of fundamental legal doctrines is much less than is commonly supposed ...." In 1886 Langdell asserted that "all the available materials" of the science of law were "contained in printed books." RECORD OF THE Commemoration, November Fifth to Erghth, 1886, on the Two Hundred and Fiftieth Anniversary of the Founding of Harvard College (1887), quoted in A. Sutherland, The Law at Harvard 175 (1967). 
cal jurists than to Holmes or to the "skeptical realists"179 he quarreled with in the 1930's.

After the Second World War still another perspective on legal history emerged. An important facet of this perspective, embodied in the scholarship of James Willard Hurst, ${ }^{180}$ was a deemphasis of "great cases" and constitutional law as subjects for historical inquiry. Hurst used Pound's "partition"181 of the legal order to emphasize the significance of lawmaking by private groups and virtually to eliminate constitutional law from his field of inquiry as a legal historian. ${ }^{182}$ Hurst's conception of legal history was, like previous conceptions, a product of the juristic mix of his time.

Hurst, like many other postwar legal scholars, became fascinated with the complex network of nonconstitutional lawmaking institutions-courts, legislatures, agencies, and private groups-whose development he witnessed in mid-twentieth century America. These scholars sought to develop a juristic posture consistent with their acceptance of modern theories of the lawmaking capacity of judges, their support of trends toward curbing the constitutionalizing function of the judiciary, and their recognition of the continued vitality of private enterprise in a regulated economy. The concept of law as a process served as their rallying point. It made possible both a partition of the legal order into institutional compartments and the retention of a vision of an integrated system; it focused upon carefully defined institutional roles consistent with institutions' respective lawmaking capabilities; it identified actions by private groups that could fairly be called exercises in making law. For these scholars, lawmaking was rational in the sense that the legal process was "purposive"183 and interrelated. The perceived rationality of the system depended upon rational action by each of its component parts. Judicial decisions had to be "reasoned" and "principled";

179 R. Pound, supra note 173 , at 28.

$180 \mathrm{~J}$. Hurst, The Growth of American Law (1950); J. Hurst, Law and the Conditions of Freedom in the Nineteenth-Century United States (1956); J. Hurst, Law and Social Process in United States History (1960) [hereinafter cited as Law and Social Process]; J. Hurst, Law and Economic Growrh (1964); Hurst, Legal Elements in United States History, in LAw IN AMERICAN HistoRy, supra note 51, at 3.

181 Pound, The Theory of Judicial Decision, 36 HARv. L. REv. 940, 956-58 (1923).

182 " $[\mathrm{M}]$ easured by continuity and impact upon distribution of functions basic to social life, much law has been constitutive which'does not fit the conventional historical preoccupation with formal constitutional law." Hurst, supra note 180, at 7-8.

${ }^{183}$ H. HART \& A. SACKs, supra note 144 , at ii. 
statutory interpretation focused on the "purpose" of statutes; agencies had to justify their "expertise." An understanding of the institutional division of the lawmaking function was a prerequisite to rational decisionmaking.

Hurst's approach reoriented scholarship in American legal history. It deemphasized "issue[s] of high politics,"184 invited empirical studies of the economic implications of lawmakers' decisions, stressed the important lawmaking role of private groups, and, in short, equated legal history with social histories of "private lawmakers" and their interaction with common law courts and legislatures. In the place of Poundian abstractions came a series of monographic studies of nonconstitutional topics. By the 1970's this perspective had become sufficiently entrenched that a general history of American law "deliberately kept to a minimum the story of constitutional law" and displayed the "influence [of Willard Hurst] . . . on every page."185

Conceptions of American legal history, in their successive emphases, reflected the changing juristic patterns marking the path of American jurisprudence. Parallels between Kent's and Story's approach and early nineteenth century perspectives on common law adjudication and constitutional interpretation have been noted. ${ }^{186}$ The attractiveness to the late nineteenth century judiciary of nonconstitutional innovations as potential constitutional principles paralleled Holmes' interest in deriving general theories of law from the common law and nonlegal practices. Pound's conceptualism reflected an early twentieth century interest in confining constitutional and nonconstitutional law to their proper ambits. Hurst's rediscovery of the importance of lawmaking by private groups and legislatures mirrored midtwentieth century efforts to define the powers of the judiciary narrowly and to recognize the multifaceted character of lawmaking in modern America. The most recent juristic mix, exemplified by an expanded jurisdiction for constitutional law and a greater tolerance for judicial scrutiny of nonconstitutional lawmaking in the name of constitutional principles, has not yet produced a parallel conception of legal history.

The recent tendency of American legal historians to equate legal history with the study of "private" law assumes a separation

184 Law and Social Process, supra note 180 , at 17.

185 L. Friedman, supra note 55, at 11.

186 Text accompanying notes 156 \& 157 supra. 
between "legal" and "constitutional" history that is untenable, given the character of American jurisprudence. American legal history has been what each generation has chosen to make it, and recent efforts have redressed an earlier overemphasis, particularly among nonlawyer historians, on political and constitutional developments. But the path of jurisprudence in America reveals a continuous interaction among constitutional.law, nonconstitutional law, and "private ordering," based on currently dominant ideas and values and on social and economic relationships. It also reveals an indispensable role for the judiciary as forger of links among those entities. Portraits of "legal history" that ignore the multiple sources of law in America and minimize the role of the judiciary are incomplete.

\section{Conclusion: Some Preliminary Reflections on the "JuRISTIC Mixes" of AMERICAN JuRISPRUdence .}

This Article has argued that certain developments that came to fruition in the early nineteenth century have given American jurisprudence its distinctive character. They include the identification of "common" (subsequently nonconstitutional) law with currently dominant social attitudes and values, the designation of a written Constitution as the supreme source of American law, and the creation of a special role for the judiciary as a constitutionalizing agent. The Article has suggested that important constitutional law decisions and influential legal scholarship in the course of American history can be reassessed from a point of view that stresses the unique features of jurisprudence in America.

If the point of view adopted in this Article stimulates further inquiry one of its premises must be submitted to more rigorous investigation. The premise is that at various times in American history ideas and events have interacted to produce a "juristic mix" out of which has emerged a dominant, distinctively new perspective on law and legal institutions.

It is not at all clear how a "juristic mix" congeals to produce a dominant intellectual perspective. This Article has attempted to identify salient features of the American intellectual and social landscape that seemed likely to have been important elements in the creation of novel modes of juristic thought. The process of combination remains elusive, however. In particular, the problem of determining the respective weight of events on ideas and ideas on events requires much greater attention. It seems far too 
simple to assert that certain "significant" events change the thinking of persons exposed to them. Are the events significant because of their intrinsic extraordinariness or because they are perceived as significant? If the latter, so perceived by contemporaries or historians? If contemporaries, what accounts for such a perception?

Although one can identify "conceptualist" or "realist" or "process" perspectives, and maintain that such perspectives played an important part in determining the respective ambits of constitutional and nonconstitutional law or in affecting the stature of judges as creative lawmakers, one cannot easily determine precisely how or why those perspectives surfaced when they did. Much more serious attention must be given to the impact of ideas on law and legal institutions, especially to the notion that dominant ideas serve as unarticulated values, forces that skew perceptions of events and institutions.

American jurisprudence, then, is much more than what appears in this preliminary survey of its origins and development. It is also the aggregate of a series of shifting dominant juristic perspectives. When the origins and impact of those perspectives are examined more rigorously we may be closer to understanding jurisprudential developments more fully. This Article outlines a path, but the rest of the wilderness remains. 